\title{
Working
}

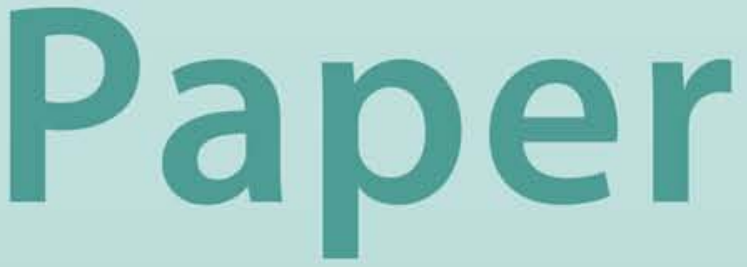


Real and Financial Sector Linkages in

China and India

Jahangir Aziz 


\title{
IMF Working Paper
}

Asia and Pacific Department

\section{Real and Financial Sector Linkages in China and India}

Prepared by Jahangir Aziz

Authorized for distribution by Steven Dunaway

April 2008

\begin{abstract}

\section{This Working Paper should not be reported as representing the views of the IMF.} The views expressed in this Working Paper are those of the author(s) and do not necessarily represent those of the IMF or IMF policy. Working Papers describe research in progress by the author(s) and are published to elicit comments and to further debate.

In the spirit of what is known as business cycle accounting, this paper finds that the investment wedge - the gap between household's rate of intertemporal substitution and the marginal product of capital-is large and quantitatively significant in explaining China's and India's growth. Specific financial sector policies are shown to map well the size and changes in the investment wedge. In the case of China, nonperforming loans, borrowing constraints, and uncertainty over changes in government guidance in bank lending, have implied large transfers from households to firms that have kept capital cost low and encouraged investment. In the case of India, post-1992 financial sector reforms, particularly the reduction in the funds preempted by the government from the banking system, has played an important role in reducing the cost of capital. Simulations show that for rebalancing growth in China and sustaining high investment rate in India, further financial sector reforms could turn out to be key.
\end{abstract}

JEL Classification Numbers:E21, E22, O4, O53

Keywords: Growth accounting, financial distortions, financial reforms, China, India Author’s E-Mail Address:jaziz@imf.org 


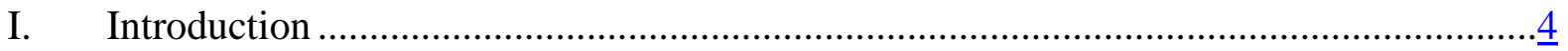

II. China and India’s Recent Growth Experience ...............................................................

III. China and India’s Economy as a Neoclassical Growth Model .........................................

IV. Calibrating the Growth Model .....................................................................................

V. Semulating the Solow Growth Model..........................................................................

VI. Investment Wedge................................................................................................15

VII. Interpreting Investment Wedges as Financial Frictions ................................................. 18

A. China's Nonperforming Loans ............................................................................

B. Borrowing Constraints and Bank Reform in China ..............................................20

C. Self-Insurance Against Administrative Controls.......................................................25

D. Financial Sector Reforms in India .......................................................................

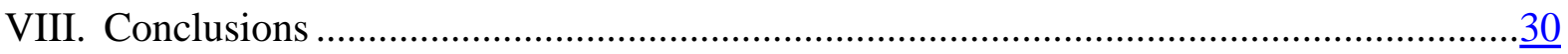

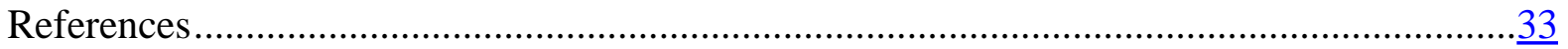

Figures

1. China and India: GDP Growth Rate.........................................................................

2. Changes in GDP Components: 1990-2005..............................................................

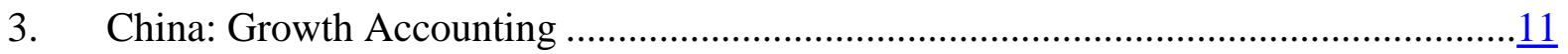

4. China and India: Labor Productivity .......................................................................11

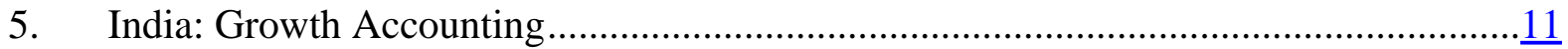

6. China: Simulation with Efficiency Wedge..........................................................13

7. China Simulation with Efficiency and Government Wedges ........................................13

8. India: Simulation with Efficiency and Government Wedges...........................................14

9. China: Derived Investment Wedge .......................................................................

10. India: Derived Investment Wedge..........................................................................

11. China: Simulation with Efficiency, Government and Investment Wedges .....................16

12. India: Simulation with Efficiency, Government and Investment Wedges .......................17

13. China: Derived Cumulative Capital Wedge ………...............................................19

14. China: Average Effective Tax Rate ………………...............................................19

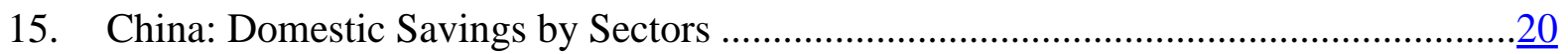

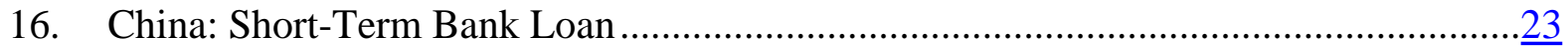

17. China: Simulation with Borrowing Constraint............................................................... 


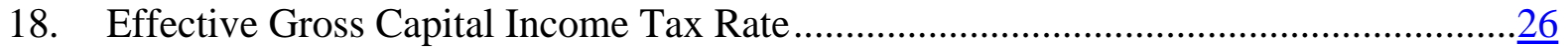

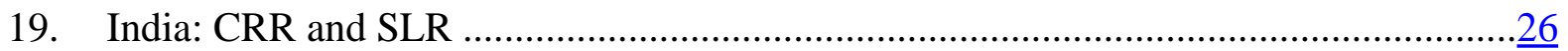

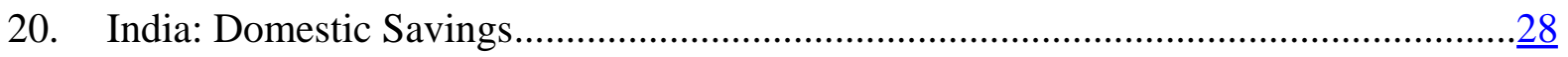

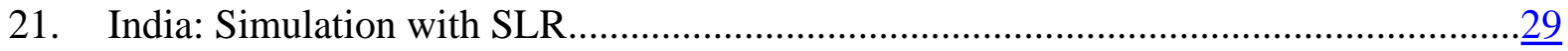

22. India: Simulation with SLR and CRR .............................................................. $\underline{30}$

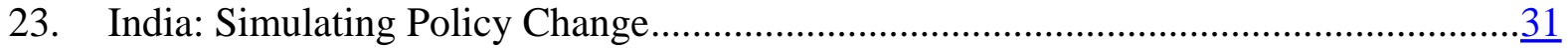

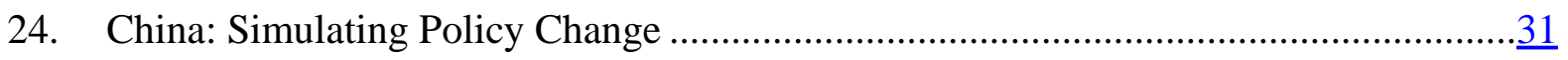

Table

1. China: Official Estimate of NPLs Created at End-2004 …......................................19 


\section{INTRODUCTION}

Much has been written about China and India's recent economic performance. And why not? With a third of the world's population and nearly two thirds of the world's poor, the sustained high growth of these two countries over the last decade is unprecedented. How these two countries have managed to sustain such high growth rates clearly hold important lessons for both development theorists and practitioners.

This paper looks into the role played by the financial sector in the growth process of China and India. The role of the financial sector in growth is an old topic and, by and large, the theoretical literature considers well-developed financial intermediation, by matching investors with savers better, to be an essential driver of growth (beginning with Schumpeter, 1911). ${ }^{1}$ The most well known formalization is the McKinnon-Shaw hypothesis that government restriction by repressing financial development adversely affects both the level of investment and productivity and thus overall growth. This argument has been reformalized in various ways (Bencivenga and Smith, 1991; Greenwood and Jovanovic, 1990; and Pagano, 1993), but the overall theme is the same. Another strand of this literature emphasizes the role played by financial development in reducing the cost of external financing by firms. Informational asymmetry or transaction costs make internal financing cheaper than external funds (Myers and Majluf, 1984). Financial development reduces these informational asymmetries and transactions costs.

The empirical side of the literature is, however, not that persuasive. Lack of sufficient data and the inability to measure the nature of financial development with available measurable indicators has been a major drawback. However, there is some (and growing) evidence to suggest that at least when variations across countries are considered then financial development appears to play a role in economic development (Beck and others, 2000; King and Levine, 1993; and Rajan and Zingales, 1998). Subject to a number of qualifications, this literature finds that financial systems directly influence growth and that well-functioning systems need stable macroeconomic policies, strong legal and information systems, a contestable environment, and regulations that empower markets through better information disclosure and increases access to markets (Demirguc-Kunt and Levine, 2008).

Supporting country-specific evidence is far harder to find as variations in financial development and institutions is typically not very dramatic for the short time period data is typically available in most countries (Athukorala and Sen, 2002). Indeed in the case of China, Aziz and Duenwald (2003) fail to find any evidence that financial development had helped growth along the channels considered important in the theoretical literature using

\footnotetext{
${ }^{1}$ This view is not unchallenged. Economic development could lead to higher demand for financial services that shows up as positive correlation between the two variables or even that financial sector development could impede growth if it leads to higher volatility discouraging risk-averse investors (Mauro, 1995; and Singh, 1997).
} 
province-level panel data. In fact, they find that most of the increased financial intermediation, proxied by higher bank deposit and lending, was used to finance the less efficient public sector that did not play a major positive role in China's growth over the period 1978-2002. However, they argue that keeping such enterprises afloat was important for preserving social stability, which may have indirectly helped growth. Bank loans were used to fund social transfers to the vast public sector employees that could not be easily re-employed in the fast growing private sector. By doing so, social stability was maintained that helped investment and growth. However, using later (survey) data, Aziz and Li (2007) find that financial constraints impeded employment growth of small and medium-scale firms, i.e., constraints on external finances affected working capital that is typically used for current expenses such as wages, although investment, which was made largely from internal savings, was not affected. Thus, while overall growth may not have been affected by the lack of financial sector development, job creation was slowed. The lack of access to external finances also appears to have played a large role in impeding the growth of firms in other countries (Ayyagari and others, 2008; and Beck and others, 2000).

In the context of India, where the financial system is usually considered to be more developed than that in China and data is more easily available, there is some evidence that financial sector development (both in terms of access and in terms of instruments available) have had a positive impact on growth (Oura and Kohli, 2008 and Allen and others, 2007). Much of the evidence supporting the positive role of financial development in India rests on the negative impact financing constraints have on firm growth and the extent to which financial sector reforms have eased these constraints. Indeed, Ghosh (2006) using data from 1995-2004 for 1141 firms finds that for both small and large sized firms, financial liberalization in India in the post-1992 period eased firms' financial constraint in funding investment.

This paper revisits this issue as the connection between growth and financial development in fast changing economies like China's and India's could be more deep rooted and complicated than what can be captured by simply looking at the relationship between available proxies for financial development and that for economic growth. The basic argument being that links between financial development and growth depend crucially on the nature of financial institutions and financial policies pursued in a country that are not well captured by available proxies, such as deposit or credit growth. Instead, financial policies and institutions change the way investment and saving decisions are made, such that looking at these decisions explicitly may provide a better sense of the connection between the financial sector and economic performance of a country.

To explore this idea within a reasonably parsimonious framework, this paper turns to a seemingly unrelated strand in the literature, namely business cycle accounting (BCA). The framework used here borrows from what has come to be known as business cycle accounting (BCA) following Chari, Kehoe, and McGrattan (2006). Early examples of this approach are the studies by Chari, Kehoe, and McGrattan (2002a and 2002b); Hayashi and 
Prescott (2002); Bergeoing and others (2002); and Kydland and Zarazaga (2004) who analyzed the Great Depression and protracted downturns in the Japanese, Mexican, Chilean, and the Argentine economies in the 1980s and 1990s.

In broad terms, the BCA literature extends the conventional one-sector Solow growth model to include various types of market imperfections or wedges that distort decisions of agents operating in otherwise competitive markets. Typically, these wedges look like simple productivity shocks, time-varying labor income and capital income taxes, and government consumption and are labeled as efficiency, labor, investment, and government wedges. However, it turns out that equilibria of a large variety of commonly-used paradigms, including those that depend on asymmetric information, financial distortions, and heterogeneity across firms and households, are found to be equivalent to those of a one-sector Solow growth model with one or more of these wedges. Thus, these wedges, despite their apparent simplicity, can reflect rich and complex economic environments and contractual arrangements among firms and households.

Data is then used to estimate the size and temporal behavior of these wedges based on explicitly derived equilibrium conditions of a neoclassical growth model embedded with simple market frictions. The estimated frictions act as a guide for the types of market distortions that are quantitatively more important than others in explaining the comovement of output, labor, consumption, and investment in the actual data. The quantitatively more important wedges are then mapped into more complex market environments that could be plausible explanations for such frictions. Once such a mapping is achieved, one has a framework to assess which structural features or institutional arrangement, policies, or reforms are relatively more important than others in explaining growth.

In deriving the wedges, preference and technology parameters in this paper were chosen to be as close as possible to the ones that are typically assumed in the literature for most countries. This is in contrast to some studies such as by Fehr, Jokisch, and Kotlikoff (2005) who choose preference parameters to match Chinese savings behavior or Bosworth and Collins (2007) and Bosworth, Collins, Virmani (2007), who choose technology parameters to match income shares of capital and labor in China and India. Fine tuning these parameters to better match the data is unappealing since it leaves little room for policy changes or reforms to play any role. Put differently, to a large extent these studies appear to be saying that the Chinese and Indian economies have performed the way they have because to a large extent households and firms in these two countries are Chinese and Indian. Instead by assuming that Chinese and Indian households have the same preferences and technological choices (as do agents in other countries), differences in economic performance are entirely due to differences in market structures, policies, and efficiency. The approach in this paper is to find China- and India-specific market distortions that may have constrained optimizing households and firms to behave is such a way that the comovements of growth, consumption, and investment in the model economies mimic those in the China and India data. 
The results from this exercise suggest that in both China and India distortions to the cost of capital may be quantitatively important in understanding their growth experience. In China, the cost of capital has been persistently lower than what would have been the case in a standard one-sector Solow growth model without any frictions. In India, the cost of capital has been persistently higher than this level. In China, the high growth, which has been largely driven by rapid investment, coincides with a negative wedge between the actual and the cost of capital derived from the standard Solow model; while in India, where growth has also been driven by investment, the wedge, while still high and positive has declined. In the case of China, the suppression of the cost of capital is a reflection of continued financial repression that has implied a large implicit tax on household's investment income. In India, the falling wedge is a sign of reduced financial repression following the reforms undertaken in the 1980s and 1990s.

The paper puts forward a number of reasons why the cost of capital has been distorted in the two countries. In China, it has been the use of the banking sector to provide cheap financing by tolerating a large level of nonperforming loans in the past and at present the large retention of corporate profits because of weak corporate governance (especially by the state) and the need for firms to self-insure themselves against state-directed credit constraints imposed on bank lending at present. In India, the cost of outside financing has been high because of lack of competition until recently, high retention of resources by the state (directly and indirectly) to finance fiscal deficits, and directed lending. As reforms have increased competition and financial repression has declined as the state has reduced deficits, the cost of capital has also fallen.

In terms of policies, reducing financial distortions in both countries turn out to be key. In China, allowing the cost of capital to reflect the true resource costs is important not only to reduce investment, but also to raise household income and consumption, both of which are needed if China is to sustain its high growth without relying on exports. The government has embarked on this rebalancing exercise to keep the economy on a sustained high growth path. The concern is that the capacity created by the continued rapid investment could potentially lead to declining prices and profits and spark another round of bank loan defaults, or the needed continued expansion in international market share, given that domestic consumption is not rising fast enough, could run up against stiffer price competition or rising protectionist pressures, especially if the global economy slows at the same time. In India, the concern is that infrastructure bottlenecks could slow growth or prevent it from increasing. Given the size of such infrastructure needs, it is likely that private sector financing will be needed such that the cost of long-term capital has to come down further. While the model here does not differentiate between different capital types, it shows that investment in India is lower than optimal (again defined with respect to the standard Solow model). If India is to raise its investment rate, cost of capital needs to be lowered through greater efficiency gains in financial intermediation. This calls for further liberalization of the financial sector. 


\section{CHINA AND INDIA's RECENT GROWTH EXPERIENCE}

Since the 1990s, China's real growth rate has averaged around 9 percent while that of India around 6 percent. India, however, went through a balance of payments crisis in 1992-93 and in recent years its growth rate has edged up closer to that of China's. By some measures the growth drivers also appear to be very similar. Since 1990, growth in both China and India has been driven by rapid investment. The investment-to-GDP ratio in China increased by

8.2 percentage points between 2000-2005, while that in India by 9.8 percentage points. Against this rise in investment, in both China and India, private and government consumption fell. In China, private consumption-to-GDP ratio fell by nearly 12.2 percentage points, while in India by 10.8 percentage points. The large difference is in net exports. In China net exports rose by 5.8 percentage points of GDP, while in India by 2.4 percentage points.

Notwithstanding the similarities, these variables in levels are very different
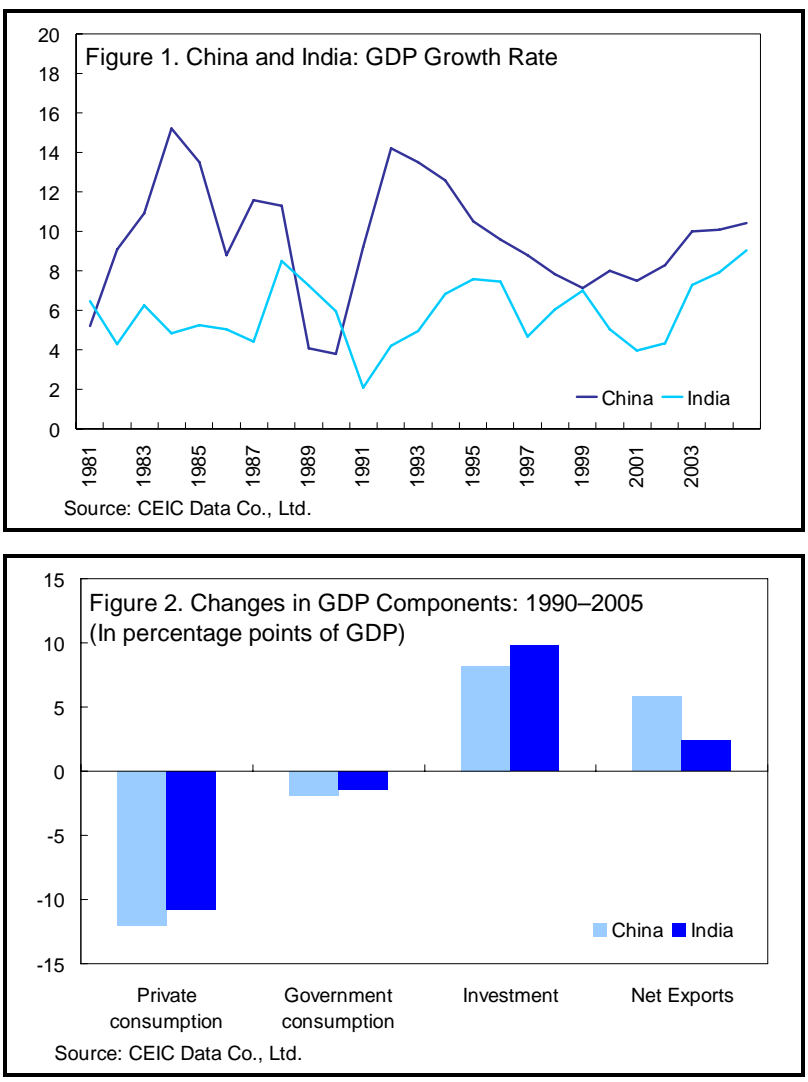
between the two economies. By 2005, China's gross investment-to-GDP ratio had reached 43 percent, while that of India's was around 30 percent. Private consumption's share in GDP in China had fallen to 38 percent — one of the lowest in the world, while that in India was around 58 percent.

\section{CHINA AND INDIA’s ECONOMY AS A NEOCLASSICAL GROWTH MODEL}

Against this background, this paper asks the question whether the standard one-sector neoclassical growth model can explain the behavior of macroeconomic variables in China and India. The answer should be no. The exercise, however, should serve as a benchmark and helps to understand the specific ways in which the two economies deviate from the standard model and thus help to pin down the market structure, institutions, and policies that may have been important.

In this one-sector economy, a representative household lives infinitely in a world of certainty, each period choosing consumption and investment to maximize lifetime utility. As is customary, households own capital and rent it out to firms and, in turn, own these firms. 
Typically, in such models, the household also chooses its working hours, and for industrial countries, this choice typically turns out to be important. In the case of both China and India, data on hours worked is hard to come by and although the International Labor Organization has some survey information, it is patchy and covers only a few manufacturing industries. Acknowledging this drawback, we drop labor choice from the household's maximization problem. This simplifies the household's problem to maximizing:

$$
\sum_{t=0}^{\infty} \beta^{t} N_{t} \log \left(c_{t}\right)
$$

subject to the budget constraint:

$$
N_{t} c_{t}+X_{t} \leq w_{t}+r_{t} K_{t}+\Pi_{t}
$$

where $N$ is the size of working-age population, $c$ is per capita consumption $\frac{C}{N}, X$ is investment, $K$ is capital, and $\Pi$ is total transfers (including government transfers net of taxes and corporate profits). There are two relative prices $-w$ the real wage rate and $r$ the real return from renting capital.

On the production side, a representative firm operates a Cobb-Douglas technology given by $Y=A_{t} K_{t}^{\alpha} L_{t}^{1-\alpha}$, where $Y$ is aggregate output, $A$ measures the level of total factor productivity (TFP), and $L$ is the number of workers employed. Using these notations, the firm's problem is to maximize profit given by

$$
\sum_{t=0}^{\infty} \lambda_{t}\left(A_{t} K_{t}^{\alpha} L_{t}^{1-\alpha}-w_{t} L_{t}-r K_{t}\right)
$$

There are two feasibility constraints in this model economy, which are the national income identity:

$$
C_{t}+X_{t}+G_{t}=Y_{t}
$$

where $G$ is government purchases, and the law of capital accumulation given by:

$$
K_{t+1}=(1-\delta) K_{t}+X_{t}
$$

where $\delta$ is the depreciation rate. To derive the policy functions and the steady-state of the system, all aggregate variables are detrended as follows:

$$
k_{t}=\frac{K_{t}}{A_{t}^{\frac{1}{1-\alpha}} N_{t}}, c_{t}=\frac{C_{t}}{A_{t}^{\frac{1}{1-\alpha}} N_{t}}, y_{t}=\frac{Y_{t}}{A_{t}^{\frac{1}{1-\alpha}} N_{t}}, \gamma_{t+1}=\left(\frac{A_{t+1}}{A_{t}}\right)^{\frac{1}{1-\alpha}}, g_{t}=\frac{G_{t}}{Y_{t}}, n_{t+1}=\frac{N_{t+1}}{N_{t}}, e_{t}=\frac{L_{t}}{N_{t}}
$$


Using these notations, one arrives at:

Aggregate production function: $y_{t}=k_{t}^{\alpha} e^{1-\alpha}$

Marginal product of capital: $r_{t}=\alpha k_{t}^{\alpha-1} e_{t}^{1-\alpha}$

Marginal product of labor: $w_{t}=(1-\alpha) k_{t}^{\alpha} e_{t}^{1-\alpha}$

Resource constraint: $c_{t}+\gamma_{t+1} n_{t+1} k_{t+1}-(1-\delta) k_{t}=\left(1-g_{t}\right) y_{t}$

Substituting and rearranging the terms (5)-(8) lead to the following three relationships:

$$
\begin{gathered}
\lambda_{t}=\frac{\beta^{t}}{c_{t} A_{t}^{\frac{1}{1-\alpha}}} \\
c_{t+1}=\frac{c_{t}}{\gamma_{t+1}} \beta\left[1-\delta+\alpha\left(\frac{e_{t+1}}{k_{t+1}}\right)^{1-\alpha}\right] \\
k_{t+1}=\frac{1}{\gamma_{t+1} n_{t+1}}\left[\left\{(1-\delta)+\left(1-g_{t}\right)\left(\frac{e_{t}}{k_{t}}\right)^{1-\alpha}\right\} k_{t}-c_{t}\right]
\end{gathered}
$$

where, $\lambda_{t}$, is the multiplier associated with the household's budget constraint. The solutions to (9) and (10) constitute the equilibrium for this economy.

The balanced growth path of the model is given by:

$$
\begin{gathered}
\frac{k_{s}}{e_{s}}=\left(\frac{\frac{\gamma}{\beta}-(1-\delta)}{\alpha}\right)^{-\frac{1}{1-\alpha}} \\
c_{s}=k_{s}\left(1-\delta+\left(1-g_{s}\right)\left(\frac{e_{s}}{k_{s}}\right)^{1-\alpha}-\gamma n\right) \\
y_{s}=k_{s}^{\alpha} e_{s}^{1-\alpha},
\end{gathered}
$$


where the variables with subscript " $s$ " denote their respective steady-state levels. In terms of the language in the BCA literature, the sequence of "Solow" residuals, $\left\{A_{t}\right\}$ given by $A_{t}=\frac{Y_{t}}{K_{t}^{\alpha} E_{t}^{1-\alpha}}$, is the efficiency wedge, while the sequence of $\left\{g_{t}\right\}$ is the government wedge.

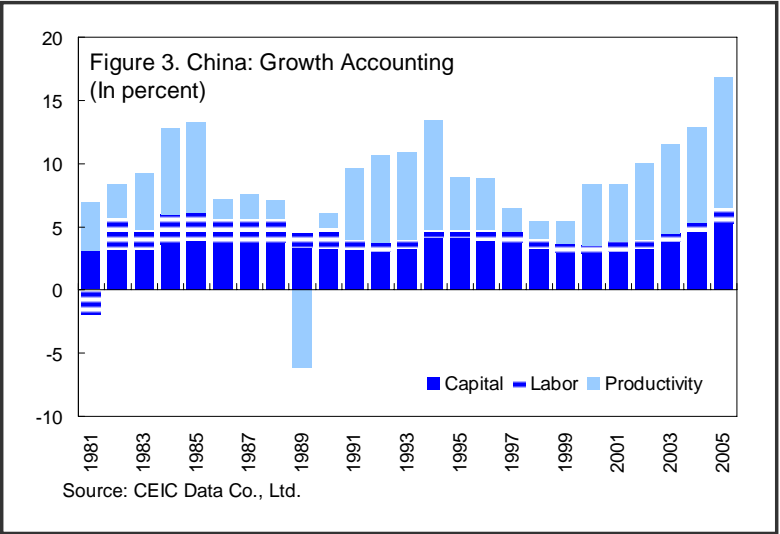

\section{Calibrating The Growth Model}

For both China and India, GNP and its components are constructed using official expenditure side data. ${ }^{2}$ Turning to the parameters of the growth model, we assume that $\alpha=0.35$, as is standard. The share of labor income in both China's and India's national income is less than 0.65 , and this is also the case in several other countries especially in the many of the fast-growing Asian economies. However, weak statistical coverage and institutional factors - such as high markups enjoyed by firms - are often cited as the causes. As a recent study shows, in most countries once such data issues are accounted for, the share of labor is around two thirds (Gollin, 2002). ${ }^{3}$
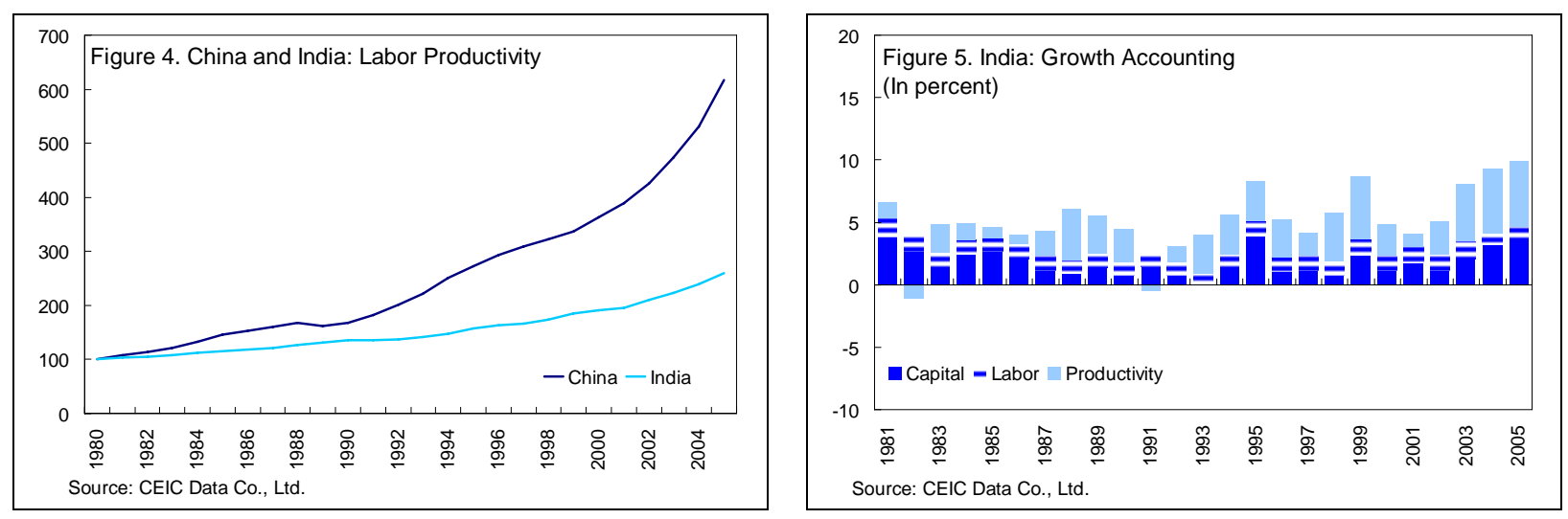

\footnotetext{
${ }^{2}$ For details on how the China expenditure side data is constructed see Barnett and Brooks (2006); Aziz (2006); and Aziz and Cui (2007).

${ }^{3}$ Interestingly, studies that have estimated production functions directly for China such as Chow (1993), Chow and Li (2002), and Heytens and Zebregs (2003), have found similar values for capital's share in national income. In the case of India,
} 
For China, the capital stock series is constructed using the perpetual inventory method. Real gross fixed domestic investment is augmented with the real current account deficit or surplus to arrive at gross national investment, which is then used to construct the capital stock series. The initial capital stock for 1979 is chosen to be such that the capital-output ratio is 2.1 as in Nehru, Swanson, and Dubey (1993), who used PPP-adjusted national accounts. The depreciation rate was chosen to be 0.06 using available breakdown between in fixed asset investment and assuming that structures last for 25 years and equipment for 10 years. In the case of India, the official capital stock series is used (and augmented using investment data beyond 2003), which has an implied average depreciation rate of around 4 percent possibly reflecting the larger share of equipment investment. Data on employment is taken from published labor statistics and includes employment in the agricultural sector for both China and India. The share of employment, $e$, is derived by deflating total employment by the working-age population, as is standard.

Using the calibrated parameters as a starting point, we first derive the sequence of the technology parameter, $\left\{A_{t}\right\}$. As can be seen from the above figure, much of the China's remarkable increase in labor productivity since the 1980s has been due to efficiency gains with substantial contribution from rising capital per worker. On the other hand, the capital-output ratio, after falling through the 1980s, rose sharply in the late-1980s and early 1990s before contracting by the mid-1990s. Since then it has risen steadily. While differing in absolute levels, the story is very similar in the case of India. Increases in labor productivity, especially in recent years have been due to significant improvement in efficiency and in capital use per worker. In both countries, but especially in China, the contribution of labor to growth has been remarkably small. Some of this could be due to poor quality of labor statistics, such that the efficiency gains may be overstated.

\section{Simulating The Solow Growth Model}

The model is next simulated for the period 1980-2005. The sequence of technological shocks is treated as exogenous with $\left\{A_{t}\right\}_{t=1980}^{2004}$ set equal to its derived value in the growth accounting exercise of the previous section, while from 2004 onwards the growth rate in TFP is set equal to its average over 1990-2004. The discount factor $\beta=0.97$, such that the long-term real interest rate is around 3 percent. As discussed earlier, $\alpha=0.35$ and the initial stock of capital set at its derived value in $\tilde{K}_{1979}$. The simulation is carried out using the "shooting algorithm" discussed in Hayashi and Prescott (2002) such that the economy reaches a balanced growth 
Figure 6. China: Simulation with Efficiency Wedge
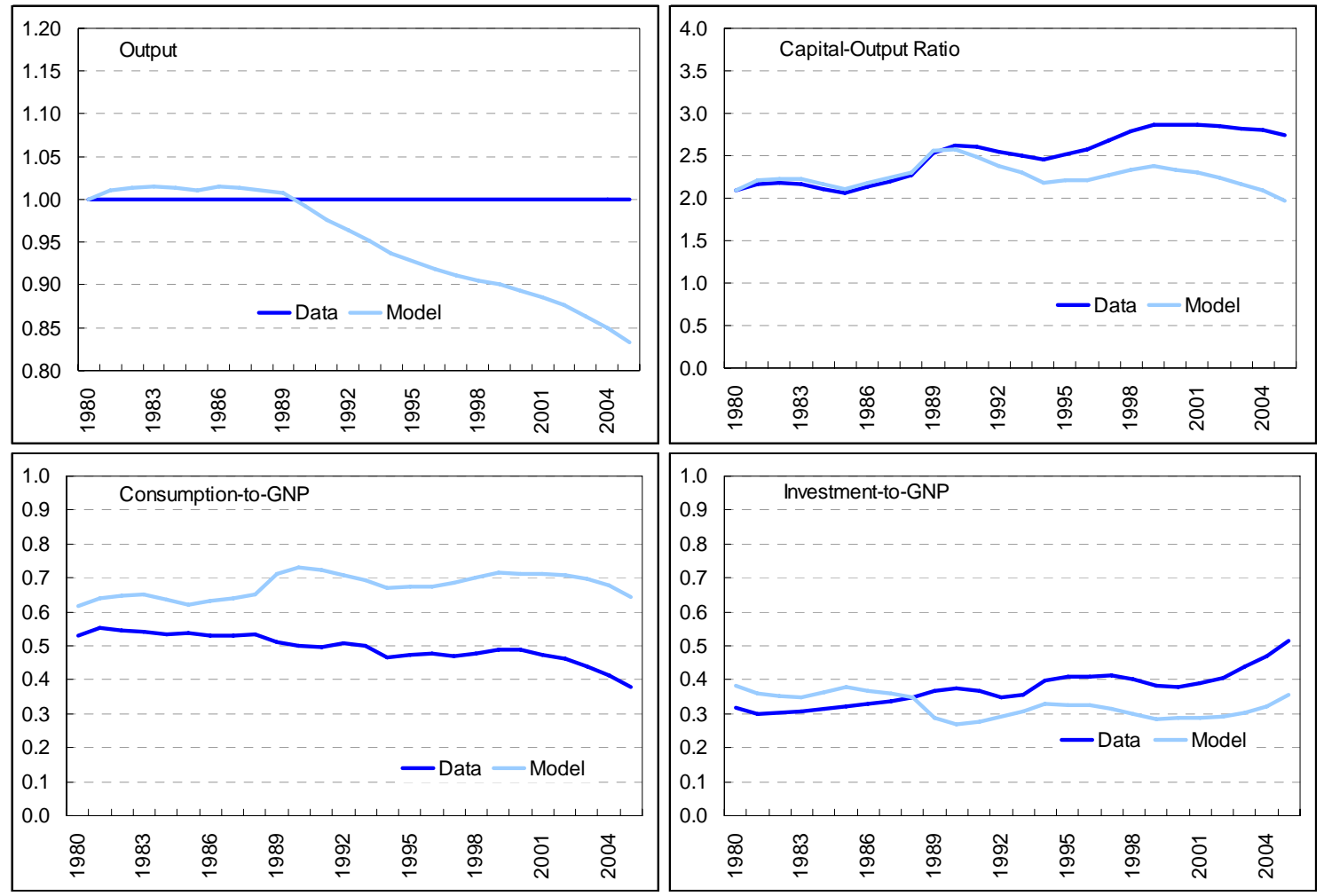

Source: Author's estimates.

Figure 7. China: Simulation with Efficiency and Government Wedges
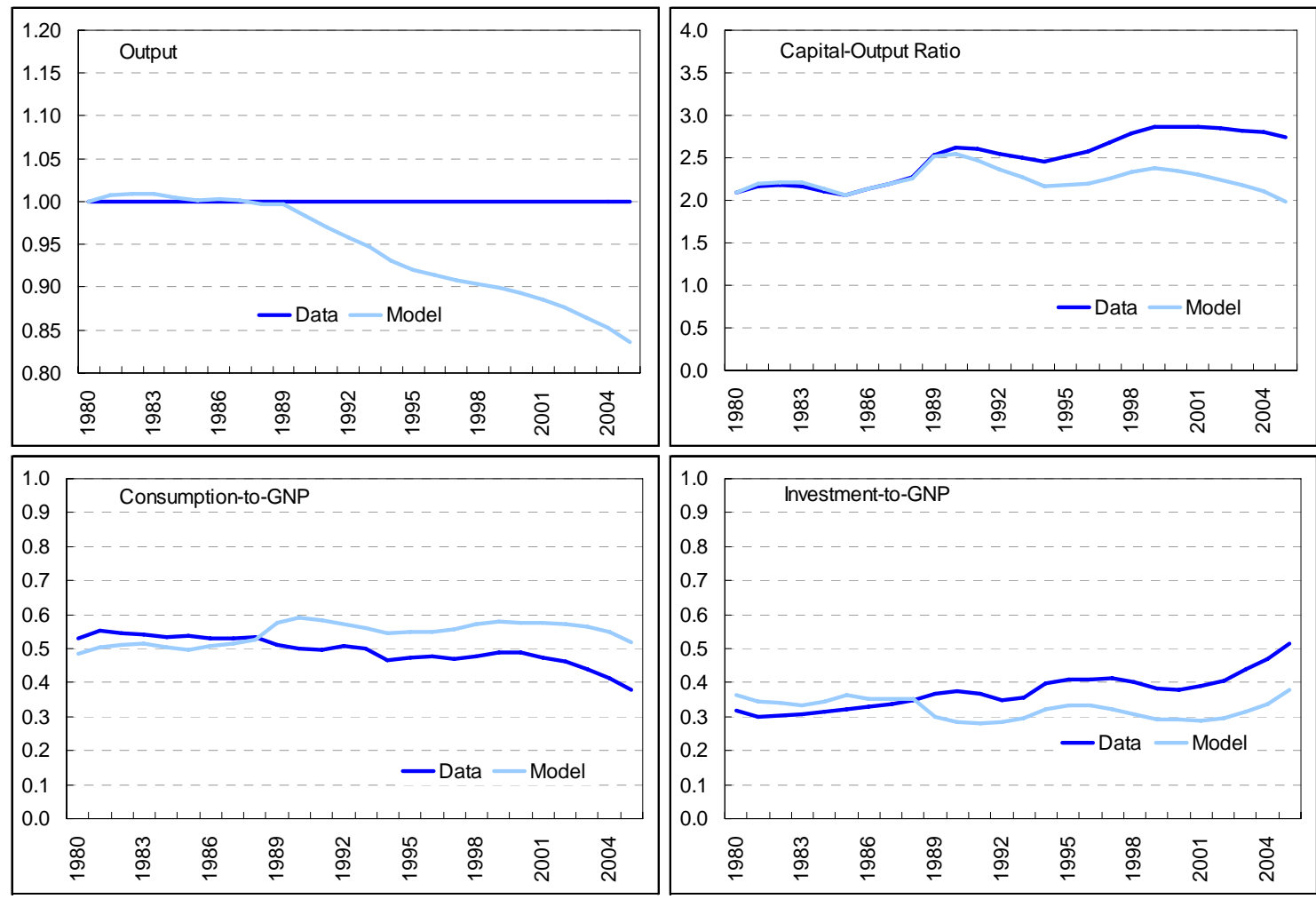

Source: Author's estimates. 
path by 2015. The algorithm requires simulating equations (9) and (10) forward for a given initial level of consumption and then solving for this initial level such that the economy is in a steady state in 2015 and beyond. Changing the terminal date does not affect the results.

In the case of both China and India, the standard Solow model fails to mimic the actual data. With $\left\{A_{\tau}\right\}$ as the only exogenous shock, the simulated output path closely traces the actual path until around the late 1980s, after which they deviate and the former ends up about 17-18 percent below the latter by 2005. Consumption's share of GNP is much higher than in the data (nearly 20 percentage points), while the investment-to-GNP ratio is that much lower. As a result, the capital-output ratio does not increase as much as it does in the data and labor productivity is lower. This in a sense underlies the current concern over China's growth pattern, namely, "too much" dependence on investment and too little on consumption. Put differently, Chinese consumers are not consuming as much as the high growth rate of the economy would imply.

Adding the government wedge improves the model's fit somewhat. The sequence of government consumption $\left\{g_{t}\right\}_{t=1980}^{2004}$, is set equal to its value in the data derived above and is assumed to remain at its 1990-2005 average level beyond 2005. Simulated output is 15 percent lower than the actual by 2005. Consumption as a share of GNP is still higher than in the data, but the gap closes to around 15 percentage points.

Figure 8. India: Simulation with Efficiency and Government Wedges
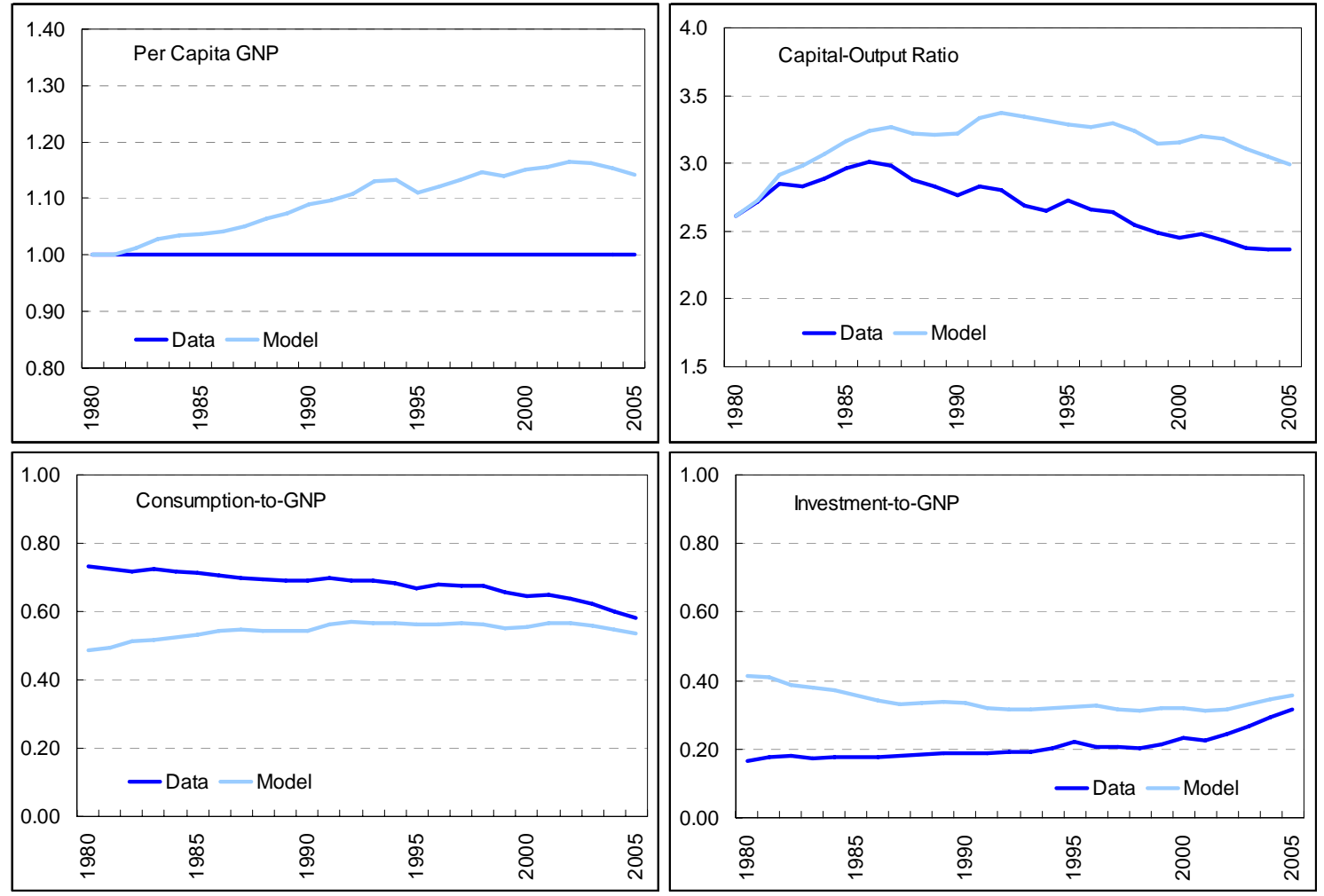

Source: Author's estimates. 
In the case of India, the model fails more spectacularly even after adding the government wedge. By 2005, simulated GNP is about 15 percent higher and through out the simulation period, simulated consumption is lower and investment higher than in the data. However, the model begins to better track the data in later years. Initially, simulated consumption is about 25 percentage points of GDP lower than in the data, but the gap narrows to around 5 percentage points of GDP by 2005. However, the continuous higher simulated investment results in the modeled capital-output ratio to be close to 3 as against 2.4 in the data by 2005 .

\section{INVESTMENT WEDGE}

An investment wedge is introduced in the model in the form of a time-varying tax on gross capital income, $\tau_{t}$ following Chari, Kehoe, and McGrattan (2006); Hayashi and

Prescott (2002). As a result, the household's budget constraint changes to:

$$
C_{t}+X_{t} \leq w_{t}+\left(1-\tau_{t}\right) r_{t} K_{t}+\Pi_{t}
$$

and the intertemporal equilibrium condition becomes:

$$
c_{t+1}=\frac{C_{t}}{\gamma_{t+1}} \beta\left((1-\delta)+\left(1-\tau_{t+1}\right) \alpha k_{t+1}^{\alpha-1}\right)
$$

As can be easily seen from equation (12), the investment wedge is essentially the difference between the marginal rate of intertemporal substitution in consumption (given the log utility function, this is just the growth rate of consumption) and the marginal product of capital. The sequence of investment wedge $\left\{\tau_{t}\right\}_{1980}^{2004}$ is computed using the growth rate of real consumption in the data, the derived sequence of capital stock $\left\{k_{t}\right\}_{1980}^{2004}$ and the calibrated parameters, $\beta$ and $\delta$.

The result is striking. Virtually all through the last two decades, the investment wedge in China has been negative. (The sharp increase in capital income tax in 1988 is an artifact of the way the wedge has been constructed and is due to a significant fall in real consumption growth in a year of very high inflation.) While in the 1980 s the wedge, on average, was positive at around 9 percent, it turned negative in the 1990s to around 25 percent, before easing modestly to 15 percent in the 2000s. In terms of return to capital, while in the 1980s, the

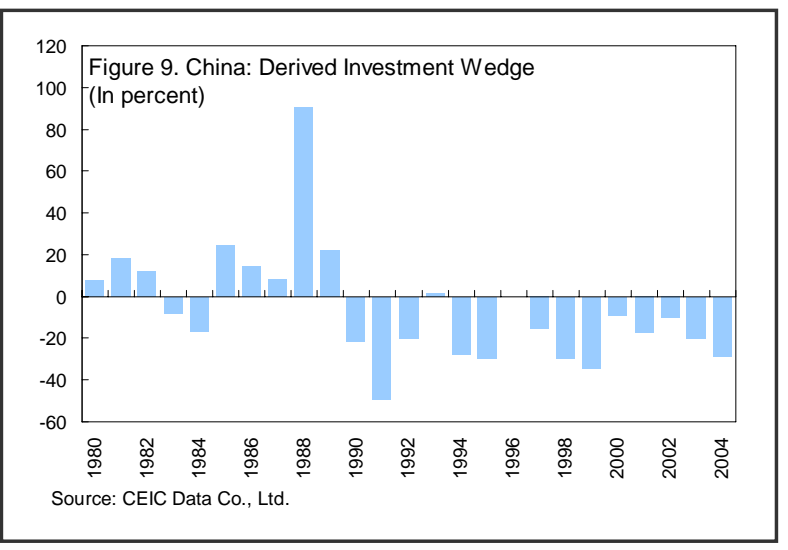
wedge reduced the return on capital by 2.6 percentage points, while it added, in the 1990s and 2000s, 3.1 percentage points and 2.2 percentage points, respectively. 
This is in sharp contrast to the investment wedge in India, where it has been positive through out the simulation period. However, after falling sharply between 1993-95 the period of immediately following the balance of payments crisis when India embarked on substantial opening of the economy and liberalization of its financial sector, the wedge increased in the late 1990s before coming down again since 2002. The positive investment wedge found in India is similar to that derived for other countries, including

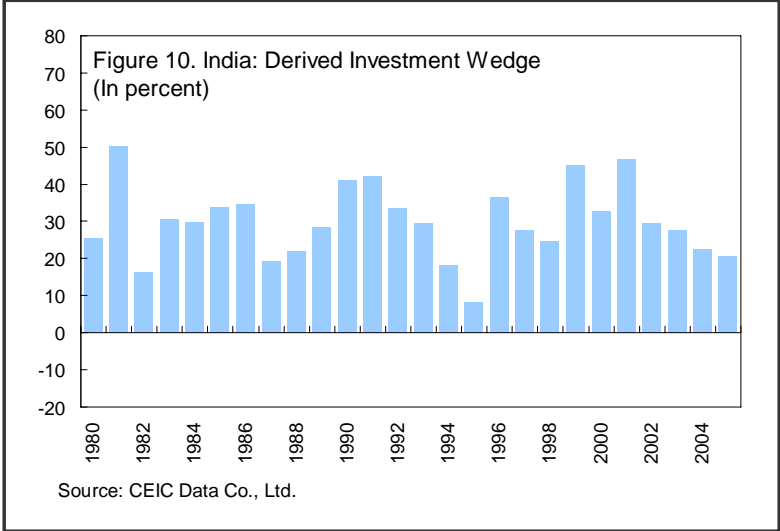
Mexico, Chile, and Japan. In these countries, the wedge is positive, reflecting not only high income tax rates, but also a variety of frictions that increase the cost of capital, although they are not explicitly captured in the sparse environment of the one-sector Solow growth model. In Japan, this wedge is broadly equivalent to the effective marginal income tax rate (Hayashi and Prescott, 2002), while in Mexico and Chile the wedges are greater than the effective tax rates suggesting other significant costs of capital (Bergoeing and others, 2002).

Figure 11. China: Simulation with Efficiency,Government and Investment Wedges
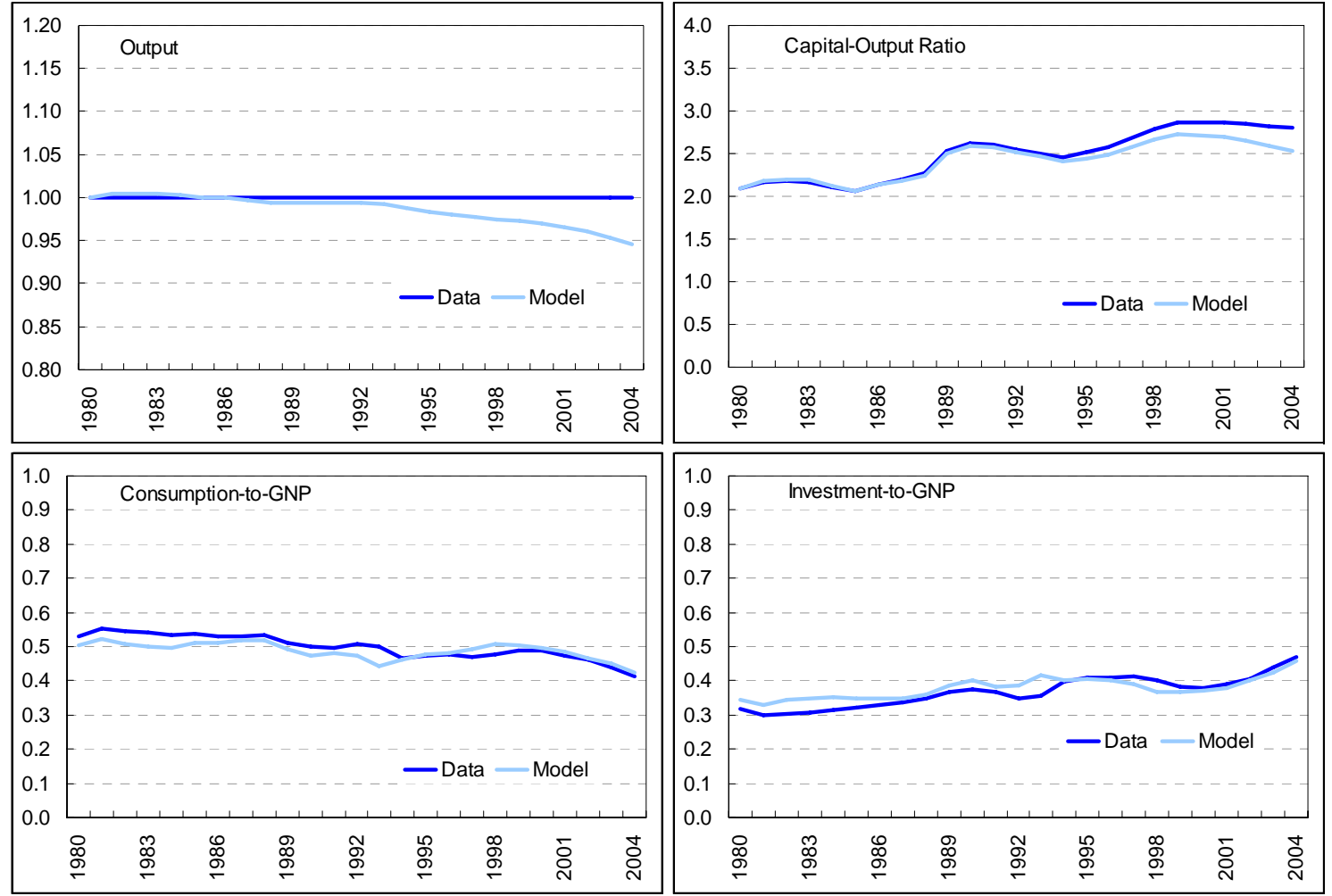

Source: Author's estimates. 
Once the investment wedge is included in the simulation, the gap between the simulated and actual data is virtually closed in the case of China. Comparing the gap when only the efficiency and government wedges were used, the cumulative effects of the investment wedge explains about 12-13 percent of 2005 GNP, and lowers the consumption-to-GNP ratio (increases the investment-to-GDP ratio) by 12-13 percentage points. These are large numbers and they underscore the role played by the distortion to the cost of capital in inducing such large investment rates. Put differently, one can construct a counterfactual scenario where an economy identical to China, except for a zero investment wedge, would reach a level of GNP in 2004, which is 5 percent lower than China's actual output, but with consumption's share of GNP 13 percentage points higher or investment's share about 13 percentage points lower.

In the case of India, similar results hold. The investment wedge explains about $13-14$ percent of 2005 GNP, increases consumption-to-GNP share by 5 percentage points and lowers that of investment by the same amount. Although for earlier years the fit is not as good, the distortion explains about 17 percentage points of the lower investment-to-GDP (higher consumption-to-GDP) in the data. While the results are not as dramatic for the later years as is the case in China, the investment wedge is a significant explanatory variable.

Figure 12. India: Simulation with Efficiency,Government and Investment Wedges
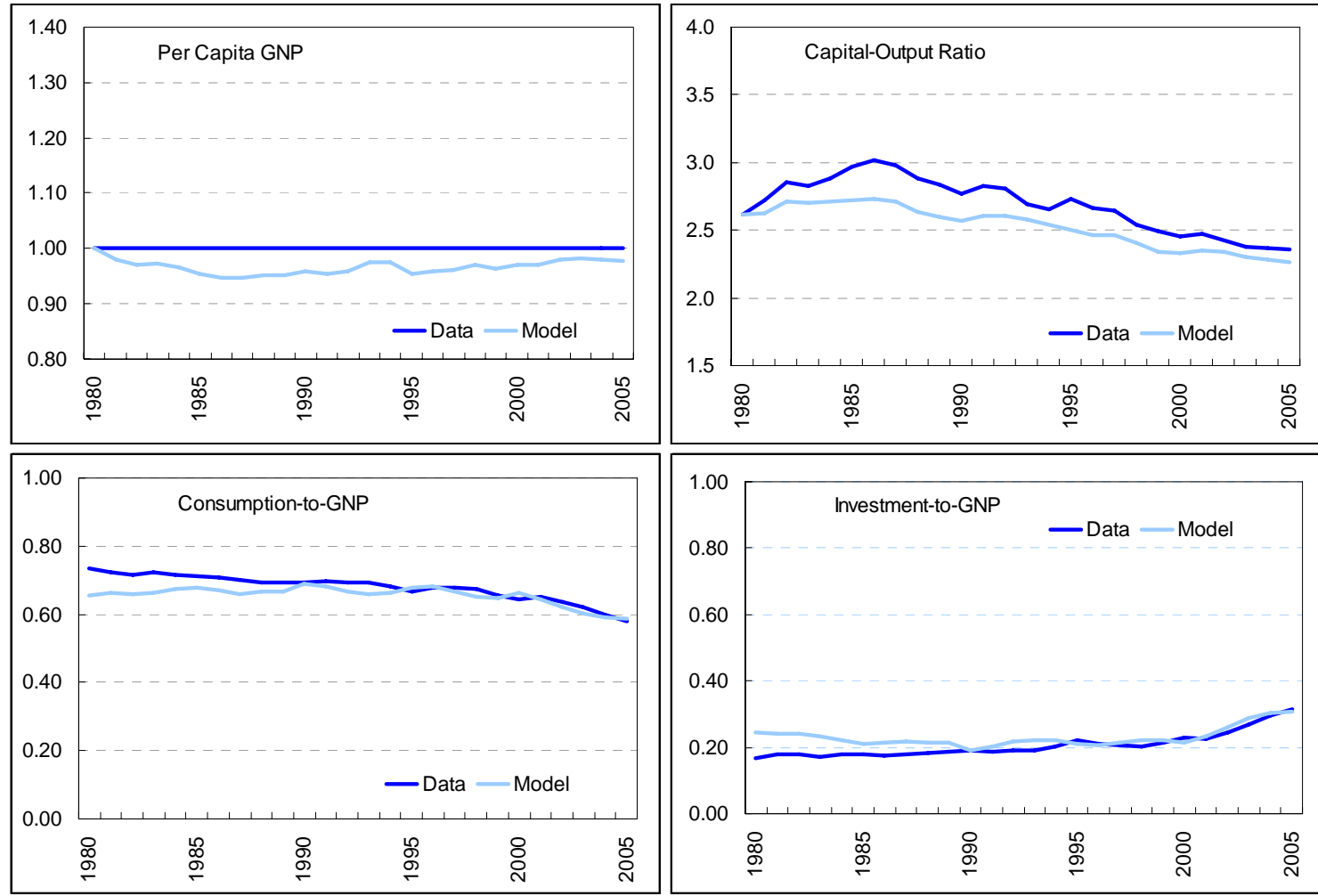

Source: Author's estimates. 


\section{INTERPRETING INVESTMENT WEDGES AS FINANCIAL FRICTIONS}

\section{A. China's Nonperforming Loans}

In the case of China, as shown in Aziz (2006) these wedges can be interpreted as financial frictions brought about by state-owned banks in China tolerating large nonperforming loans that were later (from 1999-2006) recapitalized with government funds. ${ }^{4}$ To see how this would happen, suppose the "average" or representative firm in China is one that faces a lower cost of capital because it can default on part of its loan without facing sanctions. Let $\mu_{t}$ be the proportion of loans that a firm does not repay, either because the firm does not fear effective punitive actions or the banks have been implicitly allowed to do so (what is generally called "legacy” loans) under government directives. The firm's profit, under these conditions, is given by

$$
\sum_{t=0}^{\infty} \lambda_{t}\left(k_{t}^{\alpha} e_{t}^{1-\alpha}-w_{t} e_{t}-r_{t}\left(1-\mu_{t}\right) k_{t}\right)
$$

with the associated necessary profit maximization condition $\left(1-\mu_{t}\right) r_{t}=\alpha\left(\frac{e_{t+1}}{k_{t+1}}\right)^{1-\alpha}$.

Consumers still receive $r_{t}$ which is equal to $\left(\frac{1}{1-\mu_{t}}\right) \alpha\left(\frac{e_{t+1}}{k_{t+1}}\right)^{1-\alpha}$.

It is easy to see that if one defines $\hat{\tau}_{t}=\left(\frac{\mu_{t}}{1-\mu_{t}}\right)$ then $r_{t}=\left(1+\hat{\tau}_{t}\right) \alpha\left(\frac{e_{t+1}}{k_{t+1}}\right)^{1-\alpha}$ and consumption is given by

$$
c_{t+1}=\frac{c_{t}}{\gamma_{t+1}} \beta\left[(1-\delta)+\left(1+\hat{\tau}_{t+1}\right) \alpha\left(\frac{e_{t+1}}{k_{t+1}}\right)^{1-\alpha}\right] \text {, }
$$

which is the same as equation (12).

The household's budget constraint becomes $c_{t}+x_{t} \leq w_{t} e_{t}+\left(1-\hat{\tau}_{t}\right) r_{t} k_{t}+\hat{\pi}_{t}$, where $\hat{\pi}_{t}=\pi_{t}-\hat{\tau}_{t} r_{t} k_{t}$. As a result, the two economies - the one with the investment wedge and the one with NPLs-yield identical allocations. In the steady state of such an economy,

\footnotetext{
${ }^{4}$ In addition, Anderson (2006); Lardy (1998); Karacadag (2003); and Dobson and Kashyap (2006) among other provide descriptions of how nonperforming loans were accumulated in China's banking system.
} 
$\frac{k_{s}}{e_{s}}=\left(\frac{\frac{\gamma}{\beta}-(1-\delta)}{\alpha(1+\hat{\tau})}\right)^{-\frac{1}{1-\alpha}}$ as opposed to $\left(\frac{\frac{\gamma}{\beta}-(1-\delta)}{\alpha}\right)^{-\frac{1}{1-\alpha}}$ when there is no distortion. As is easily

evident a higher $\hat{\tau}$ leads to a higher capital stock in the steady state.

The question, of course, is whether this effect was large enough to matter at the macroeconomic level. Based on official estimates, the stock of NPLs that was created in the last 10-15 years would, at the end of 2004 amount to around 26 percent of GNP. In addition, banks in China also carry "special mention" loans, which are loans that are not being fully serviced at present, but for legal reasons or because the corporate client is undergoing restructuring, they are not classified as nonperforming. It is possible that some or substantial portion of these loans could turn out to be nonperforming. The fourth large bank, Agricultural Bank of China, is the second largest in terms of deposits and is still without a formal restructuring plan. It is possible that when such a plan is put in place the bank's recorded NPLs will increase. In the prototype economy with the investment wedge, the accumulated stock of net negative wedge at the end of 2004 stood at around 60 percent of 2004 GNP (assuming a zero starting stock in 1990).

\begin{tabular}{|cr|}
\hline \multicolumn{2}{|c|}{ Table 1. China: Official Estimate of NPLs } \\
Created at End-2004 \\
(In billions of renminbi) \\
\hline Reported NPLs on balance sheet \\
NPLs transferred to AMCs & 1,575 \\
Original transfer in 1999-2000 & 1,770 \\
Additional BOC and CCB transfer & 1,420 \\
Write-offs & 350 \\
Total & 324 \\
(In percent of 2004 GNP) & 3,668 \\
Special mention loans & 25.8 \\
(In percent of 2004 GNP) & 1,140 \\
\hline
\end{tabular}

However, it is typically the case that there is a time lag between when a loan becomes nonperforming in the economic sense and when it gets classified as such in the accounting sense. If this time lag were about two years, which is not atypical of Chinese banking practice, then the reported NPLs in 2004 would be reflecting NPLs created in 2002.
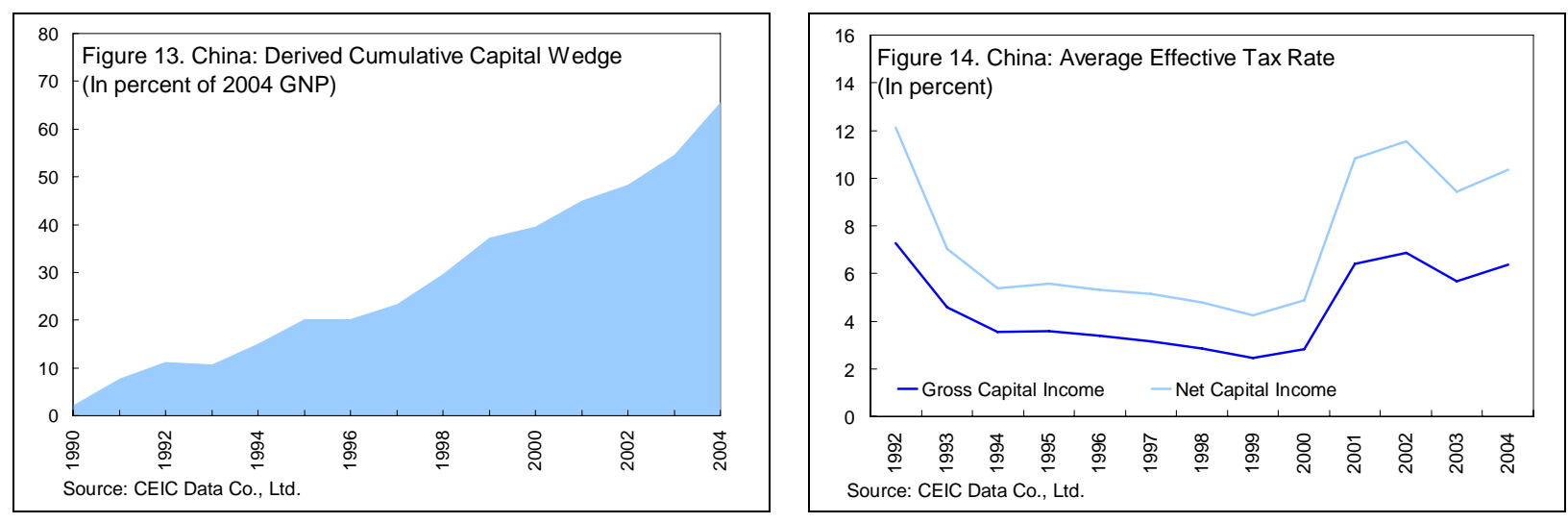

Taking into account the time lag in reporting, the 2002 negative wedge in terms of the 2004 GNP of the prototype economy stands at around 46 percent. However, one needs to add to this capital income tax received by the government. In China, the flat income tax rate is 
currently 33 percent for domestic firms and 15 percent for foreign firms. However, the effective average income tax rate has been around 4-5 percent (on gross capital income), on average, since the early 1990s, and is around 6-7 percent. $^{5}$ This reflects a wide range of general and specific concessions awarded to firms. Using the above corporate tax rates and adding the derived capital income tax to the net wedge raises the gross wedge that would be reported in 2004 in the prototype economy to around 48 percent of GNP. This is still higher than the created NPLs reported by Chinese banks, but closer to estimates by outside analysts such as Anderson (2006). While an exact mapping of the reported NPLs and the model-based wedges cannot be established, it is clear that NPLs may have been a major conduit through which investment was supported and that the wedge derived from the Solow growth model is not unrealistic.

\section{B. Borrowing Constraints and Bank Reform in China}

However, in the last few years significant progress has been made in reforming China's banking sector. And although it may be too early to evaluate the impact of these reforms on bank behavior (Podpiera, 2006), it appears that at least the three big banks (BOC, CCB, and ICBC) may have put in place internal controls which could have potentially slowed the creation of new NPLs. Yet the estimated investment wedge appears to have increased in the last few years, although, on average, it is lower than in the 1990s.

To address this issue, one needs to look into a particularly striking feature of the Chinese economy, namely, that corporate savings is the largest source of financing investment. A cursory look at the breakdown of savings across sectors shows that while household savings has fallen from around 21 percent of GDP in the early 1990s to 19 percent of GDP in 2004, corporate and government savings, on the other hand, has steadily increased. In fact, during the past five years, enterprise and government saving each rose by around 4 percentage points of GDP, and they now

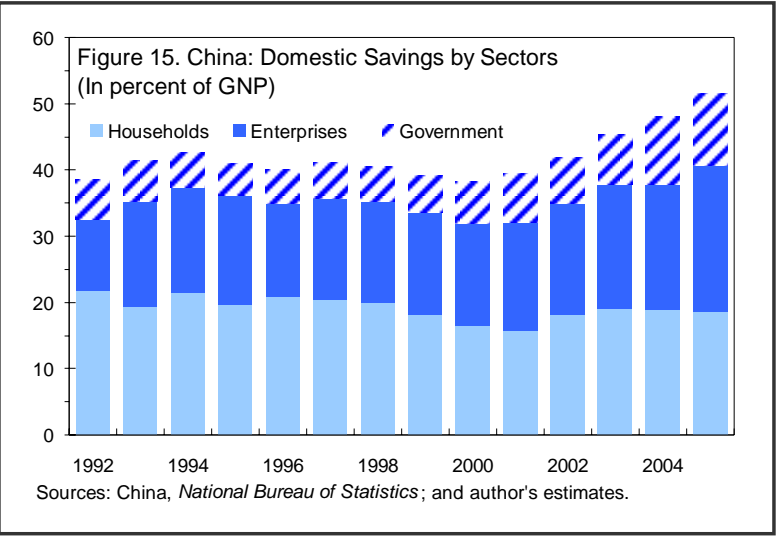
represent around 19 and 10 percent of GDP, respectively.

The dominance of internal savings in financing investment is in a large part due to the structure of firm ownership and China's poor financial intermediation, i.e., due to an

\footnotetext{
${ }^{5}$ The rate is somewhat higher around 9-10 percent on capital income net of depreciation. Note that these are the average effective tax rates, and not the marginal tax rates. Given the lack of adequate information, it is difficult to compute the marginal rate. In addition, data on capital income tax is available only from 1992 as published in the China Statistical Yearbook, prior to this period separate income tax data is not available.
} 
underdeveloped banking system, which has been unable to meet the investment needs, particularly of the vast number of small and medium-scale enterprises, many of whom are in the private sector. Surveys and studies show that the private Chinese firms are constrained in their access to credit. Such constraints reflect the lending practices and regulatory framework that favor the state-owned enterprises over the private firms (Huang, 2003), the lengthy bank restructuring since the late 1990 s, which discouraged lending until recently, and the underdeveloped bond and equity markets, which provide few channels of indirect financing. Indeed, according to the business environment survey conducted by the World Bank, the share of Chinese firms that complain about access to financing as a key obstacle to their business is significantly higher than other East Asian economies. The smaller the firms, the more constrained they are. ${ }^{6}$ This of course does not preclude many other firms, especially the large SOEs, from borrowing from banks without facing any constraints. Aziz (2006) shows that characterizing the representative firm as being credit constrained leads to a distortion that is quantitatively large enough to explain the observed aggregate behavior of consumption and investment.

To illustrate the nature of this problem, assume that due to firms' limited commitment households (or banks) are not willing to lend without collateral and the capital owned by entrepreneurs (the owners of firms) can only be used for this purpose. However, in the presence of the borrowing constraint, a firm's return to saving an additional unit of capital is not only the marginal product of capital it receives next period but also the "return" from loosening the borrowing constraint. Thus, the return to internal savings of entrepreneurs is higher than the marginal product of capital as long as the borrowing constraint is binding, and this could lead to higher accumulation of capital than otherwise. The detailed microeconomic environment where such borrowing constraints appear as optimal arrangements is not discussed in Bernanke and Gertler (1989) and Carlstrom and Fuerst (1997).

Assume that wages are paid in advance of production each period and therefore firms need to borrow funds to do so. Since there is no uncertainty in the model, the setup is difficult to justify and should be seen only as a device to introduce the use of working capital. In particular, it is also assumed that all working capital is borrowed and all investment is undertaken from internal savings of firms. This is clearly an extreme assumption as firms borrow both for working capital and for investment purposes. The assumption, however, keeps the model simple and helps to highlight the issue.

\footnotetext{
${ }^{6}$ The World Bank survey taken in 1999 showed that 80 percent of private firms face financial constraints in China, and Chinese firms' reliance on retained earnings is higher than in other countries.
} 
The household's budget constraint: changes to $c_{t}+\gamma_{t+1} n_{t+1} l_{t+1}-l_{t} \leq w_{t} e_{t}+r_{t} l_{t}+\pi_{t}$, where $l_{t}$ is the household's savings. Firms maximize

$$
\sum_{t=0}^{\infty} \lambda_{t}\left(k_{t}^{\alpha} e_{t}^{1-\alpha}-\left(1+r_{t}\right) w_{t} e_{t}-\left(\gamma_{t+1} n_{t+1} k_{t+1}-(1-\delta) k_{t}\right)\right)
$$

subject to

$$
\left(1+r_{t}\right) w_{t} e_{t} \leq \theta_{t} k_{t}
$$

As noted earlier, wages need to be paid before production so that firms need to borrow $w_{t} e_{t}$. However, the funds that a firm can borrow are subject to a collateral constraint. The only collateral is the capital the firm owns. And this is the key institutional set up that drives the result. In other papers that have used a similar set up, such as Chakraborty (2005) and Kobayashi and Inaba (2006) in the case of Japan during the 1990s, the collateral is either land or equity, both of which are difficult to pledge as collateral given China's private property rules. In addition, until 2006-07 the stock market was not a significant source of financing. How representative is this stylization of the Chinese economy? Using the World Bank survey of firms, Aziz and Cui (2007) show that 40 percent of all firms and 80 percent of privately owned firms are financially constrained in meeting their working capital needs and that this constraint adversely affects the number of workers firms employ. The average employment growth for firms that are not financially constrained is about 5.5 percent annually, while in firms that reported facing financial constraints employment growth was less than 0.8 percent per year. In contrast, financial constraint had no impact on firm investment, i.e., the investment growth was statistically the same for firms that were financial constrained and those that were are not. This evidence and the fact that neither land nor equity can be pledged as collateral given China's private property rules (only after the 2007 reforms is urban land treated as private property) suggests that assuming that firm capital is the only source of collateral is not an unrealistic stylized representation. Banks lend to firms such that its debt service, $\left(1+r_{t}\right) w_{t} e_{t}$, does not exceed, $0<\theta_{t}<1$, fraction of the firm's capital stock.

After some substitutions, when the borrowing constraint is binding the equilibrium conditions for this economy become:

$$
\begin{gathered}
c_{t+1}=\frac{c_{t}}{\gamma_{t+1}} \beta\left(1-\delta+\left(\frac{e_{t+1}}{k_{t+1}}\right)^{1-\alpha}-\theta_{t+1}\right) \\
r_{t}=\alpha\left(\frac{e_{t}}{k_{t}}\right)^{1-\alpha}-\theta_{t}-\delta \\
k_{t+1}=\frac{1+r_{t+1}}{\left(1+r_{t+1}+\theta_{t+1}\right) \gamma_{t+1} n_{t+1}}\left(\left(1-g_{t}\right) y_{t}+(1-\delta) k_{t}-c_{t}+\frac{\theta_{t} k_{t}}{\left(1+r_{t}\right)}\right)
\end{gathered}
$$


And in steady state, $\frac{k_{s}}{e_{s}}=\left(\frac{\gamma}{\beta}-(1-\delta)+\theta_{s}\right)^{-\frac{1}{1-\alpha}}$

Comparing this steady state with that of the standard model, it is clear that capital will be higher as long as $\theta_{s}$ is appropriately small.

As before, define $\hat{\tau}_{t}=\frac{(1-\alpha)\left(\frac{e_{t}}{k_{t}}\right)^{1-\alpha}-\theta_{t}}{\alpha\left(\frac{e_{t}}{k_{t}}\right)^{1-\alpha}}$, then the household savings function (13),

becomes $c_{t+1}=\beta \frac{c_{t}}{\gamma_{t+1}}\left((1-\delta)+\left(1+\hat{\tau}_{t+1}\right) \alpha\left(\frac{e_{t+1}}{k_{t+1}}\right)^{1-\alpha}\right)$,

which is equivalent to equation (12) and the borrowing constraint looks identical to an investment wedge. This wedge will be positive, i.e., the implicit rate of return to capital will be higher than in the standard model as the borrowing constraint is binding. To see this note that when the borrowing constraint is binding $(1-\alpha)\left(\frac{e_{t}}{k_{t}}\right)^{-\alpha}-\left(1+r_{t}\right) w_{t}>0$ and $\theta_{t} \frac{k_{t}}{e_{t}}=\left(1+r_{t}\right) w_{t}$, and thus $(1-\alpha)\left(\frac{e_{t}}{k_{t}}\right)^{1-\alpha}-\theta_{t}>0$. Consequently, the equilibrium of such an economy will look the same as one where there is negative tax on capital income equivalent to $\hat{\tau}$. In a period when banks are restructuring, such as in recent years in China, banks become more cautious about their lending. This intensified the borrowing constraints faced by firms, increasing the returns from loosening the constraint and encouraging firms to increase internal savings.

It is difficult to pin down the value of $\theta_{t}$ from Chinese banking data as working capital is not separately recorded. While prudential norms related to maximum loan-to-value ratios exist, it is unclear how extensively these have been implemented and to what extent they have been binding. Approximating working capital as short-term loans (less than one-year maturity) less trade credits, data from 1999-2005 reveals that the ratio of such loans to capital stock has been declining and on average over this period the ratio stood around 0.25 . For simulation purposes, two

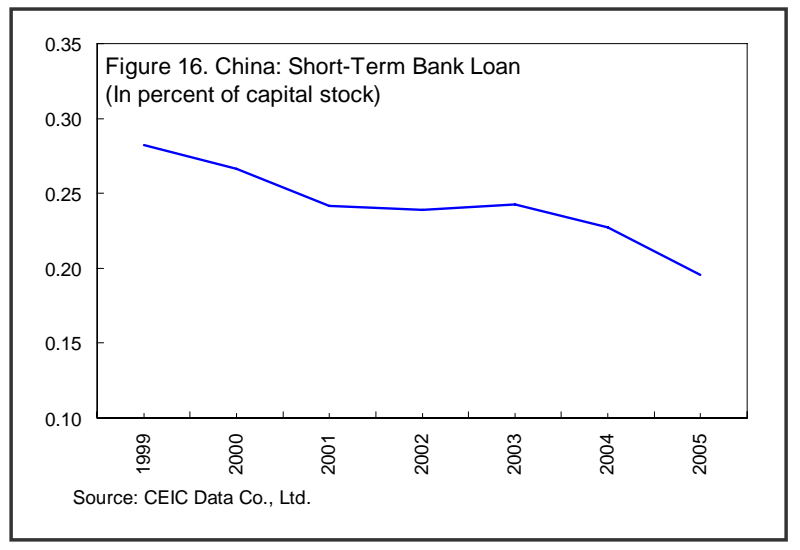


experiments were conducted. In the first, $\theta_{t}$ was set to 0.25 for the entire period 1980-2004, and in the second experiment it was raised to 0.4 for 1980-1989 and lowered to 0.25 from 1990-2004. With $\theta_{t}=0.25$ for the entire period, the simulated consumption and investment path tracked well the data for the period 1990-2004, but did rather poorly in the 1980s, when simulated consumption was too low and investment too high compared to the data. This suggests that the borrowing constraint may not have been that severe in the 1980s. Easing the constraint by increasing $\theta_{t}$ to 0.4 in the $1980 \mathrm{~s}$ improves the fit of the simulation better (Figure 5). Indeed, for this path of $\left\{\theta_{t}\right\}$ the simulated consumption and investment path tracks the data on consumption and investment quite well. However, the implied path for output tracks the data less well. By 2005, simulated GNP is about 10 percent below that in the data. In the absence of firm evidence on $\theta_{t}$, it is difficult to ascertain the contribution of this factor. What the exercise shows is that such borrowing constraints can potentially explain some part of the consumption-investment comovement in the Chinese data and that it is possible that the recent bank reforms have led to a tightening of the constraint that may have induced higher internal savings by firms.

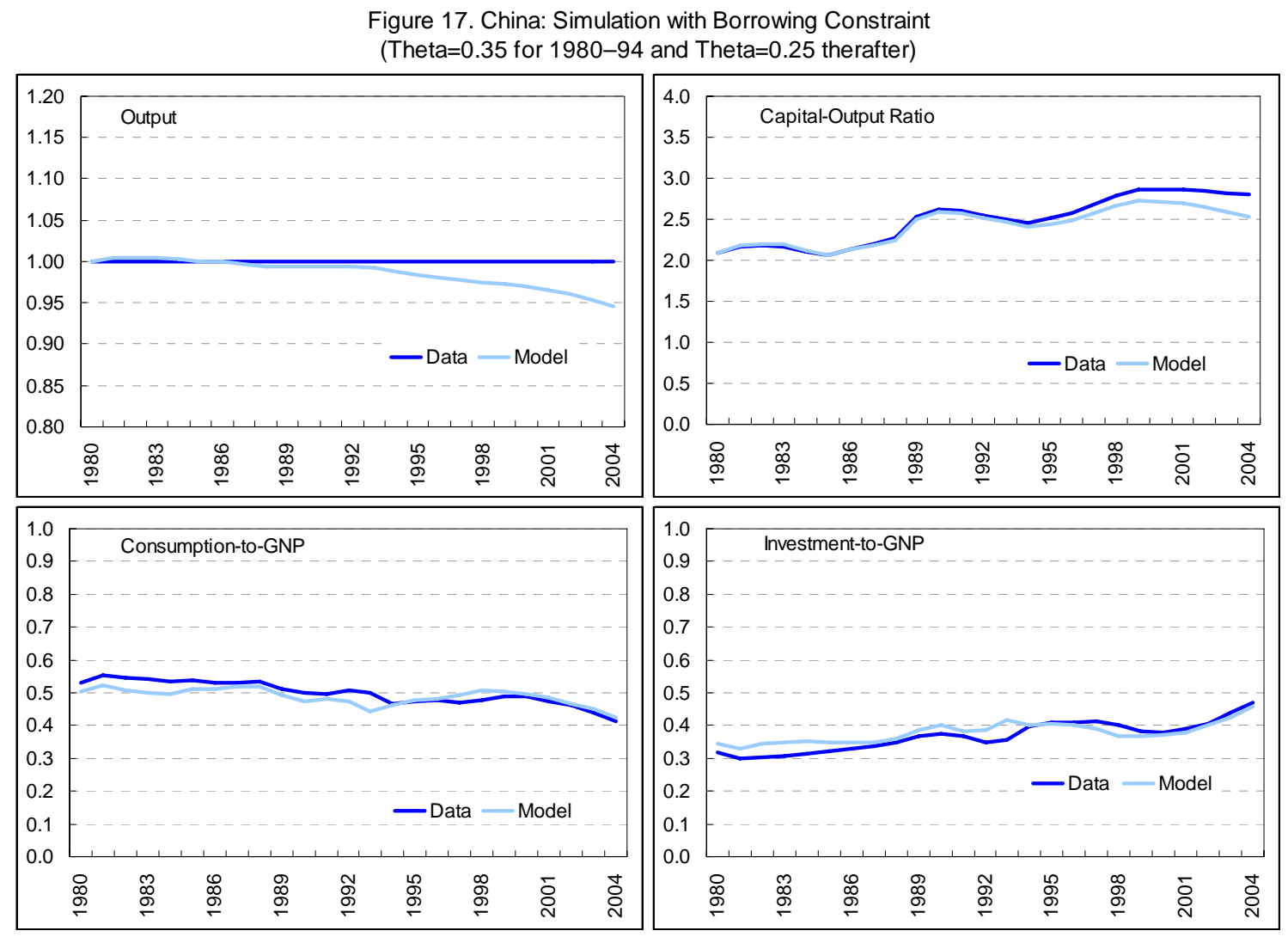

Source: Author's estimates. 


\section{Self-Insurance Against Administrative Controls}

Another reason why firms have been increasing internal saving may have to do with the way government has tended to guide lending. While government has steadily removed itself from intervening directly in the economy, one of the indirect ways it has retained its intervention is by guiding lending to specific sectors depending on what it has viewed as being priority areas for investment. Much of this has been on allocating resources sectorally, but to some extent this practice has also been a tool to control overall investment. In general, the government has tried to control investment from going to sectors with overcapacity through administrative orders. Depending on its reading of the economic situation, the government has made changes to the sectors in the guidance list. While the objective of this guidance has been to influence the sectoral allocation of investment funds, the practice may have had a general impact on firm behavior. Given that the government could change the status of a sector in the guidance list, all firms are faced with uncertainty over whether banks would provide loans or not. As this type of uncertainty is uninsurable, firms have sought to self insure through retaining profits as internal savings, and a rise in this uncertainty would lead to high corporate savings.

To see the impact of such government policy more clearly, the standard model is altered in the following way. At the end of each period, a firm applies to a bank for a loan. Bank loans are in the form of contracts that specify the interest rate and the amount, i.e., $\left\{r_{t}, x_{t}\right\}$. With probability $\varepsilon_{t}$ the loan is approved and with probability $1-\varepsilon_{t}$ the loan is rejected. If the loan is rejected, the firm carries out production only with the capital stock it owns, otherwise it borrows the amount that it needs. Labor decisions by the firm are taken before the loan is approved. This assumption is needed to make the loan approval matter in equilibrium. To see this suppose a firm decides on its hiring decision after the bank loan is approved. In this case, firms with higher capital will hire more workers than firms with lower capital. Given that the technology follows constant returns to scale, aggregate output will not be affected by this contractual change. As government policy in China is used to channel funds to certain sectors and away from others, the probability of approval is sector-specific with some sectors facing a lower probability of rejection than others. However, to keep the analysis tractable here, it is assumed that all firms face the same risk and $\pi_{t}$ is drawn independently each period, i.e., it is the risk faced by the representative firm. The firm's problem now becomes:

$$
\operatorname{Max} \sum_{t=0}^{\infty} \lambda_{t}\left(k_{t}^{\alpha} e_{t}^{1-\alpha}-\left(\gamma_{t+1} n_{t+1} m_{t+1}-(1-\delta) m_{t}\right)-w_{t} e_{t}-r_{t} x_{t}\right)
$$

subject to $x_{t}>0$ with probability $\varepsilon_{t}$ and $x_{t}=0$ with probability $1-\varepsilon_{t}$.

As shown in Aziz (2006), letting $\rho_{t}=\frac{m_{t}}{k_{t}}$ be the share of firms' own capital to total capital the equilibrium condition in this economy can be written as 


$$
\begin{aligned}
& c_{t+1}=\beta \frac{c_{t}}{\gamma_{t+1}}\left((1-\delta)+\left(1+\hat{\tau}_{t+1}\right) \alpha\left(\frac{e_{t+1}}{k_{t+1}}\right)^{1-\alpha}\right) \text {, where } \\
& \hat{\tau}_{t}=\varepsilon_{t+1}\left(\frac{\varepsilon_{t+1}}{1-\rho_{t+1}\left(1-\varepsilon_{t+1}\right)}\right)^{1-\alpha}+\left(1-\varepsilon_{t+1}\right)\left(\frac{1}{\rho_{t+1}}\right)^{1-\alpha}-1
\end{aligned}
$$

This is again equivalent to equation (12). This expression for $\hat{\tau}_{t}$ is strictly positive as long as $0<\varepsilon_{t}<1$ and $0<\rho_{t}<1$ and thus $\hat{\tau}_{t}$ appears as a negative tax, raising the return on internal savings by firms above the marginal product of capital because of its self-insurance value. In addition, as $\varepsilon_{t}$ falls, i.e., the probability of being credit constrained increases, the wedge, $\hat{\tau}_{t}$, also increases. This provides greater incentive to save. While China's state planning commission (NDRC) lists industries that are not in a priority sector or where there maybe overcapacity to banks and this list changes over time, it is difficult to use this information to estimate $\left\{\varepsilon_{t}\right\}$. Although quantitative estimates are difficult to come by, it is possible that this factor also played a significant role in the rise in China's corporate savings in recent years.

\section{Financial Sector Reforms in India}

Turning to India, as the investment wedge is positive and large, a natural place to start is with capital income tax. As in China, the statutory capital income tax rate is high40 percent in earlier years and 35 percent in later years. However, the average effective tax rate is not. As shown in Poirson (2006) the average effective tax rate in the 1990s and the early 2000s was around 5.2 percent. (Data limitations prevent extending the effective rate calculation

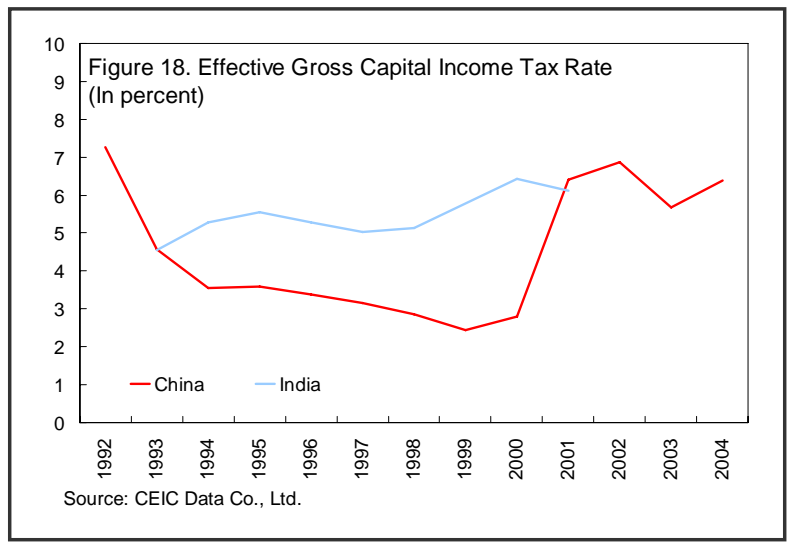
beyond 2003). While the marginal tax rate is likely to be higher, typically $1 \frac{1 / 2-2}{2}$ times that of the average rate, it is unlikely to be a big explanatory variable given that the investment wedge averaged around 25 percent fluctuating between 40-10 percent.

This brings up financial sector reforms as a candidate explanation. In the case of China, financial repression in the form of high tolerance for nonperforming loans and the use of firm capital as collateral for bank

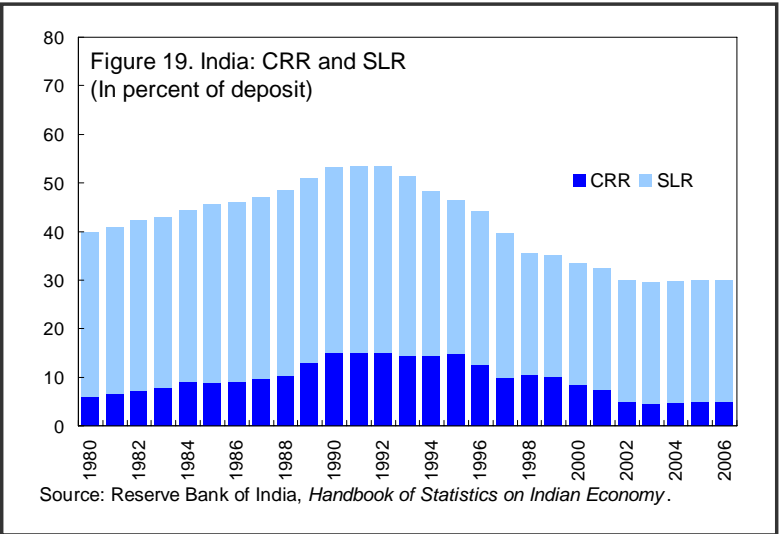


financing depressed the effective cost of capital, thereby leading to overinvestment (compared to the level predicted by the standard Solow growth model). In the case of India, financial repression in the form of preemption of loanable funds by the state to finance its deficits and over regulation of the banking sector and capital markets kept the cost of capital for the private sector at elevated levels until recent reforms. While financial sector reforms began in 1985, quantitative controls on bank loans remained strong with high reserve ratio (CRR) and statutory liquidity ratio (SLR), the latter used as a tool for captive fiscal deficit financing. By 1991, the CRR (15.5 percent) and SLR (38.5 percent) together preempted more than half of bank deposits. Since 1992, as part of a wider reform package in response to the balance of payments crisis, wide-ranging banking and capital market reforms have been implemented.

These reforms are well described in several papers including (Bery and Singh, 2006; Singh, 2005; Panagariya, 2004; and Mohan, 2005). No attempt is made here to exhaustively list them, instead some of the main ones are pointed out. Clearly among the most important was the end of administered interest rates. ${ }^{7}$ As a result of these changes, both deposit rates and lending rates have on average fallen since 1992. At the same time, both the CRR and the SLR were cut significantly, although the SLR remains around 25 percent. In addition, entry and branch expansion requirements for domestic private banks were eased and from 2003 for foreign banks. Moreover, prudential norms were rationalized and public sector banks recapitalized both through the budget and the market. Alongside banking reforms, the government also undertook major capital market changes, in particular through the repealing of the 1947 Capital Issues Act and the enactment of the SEBI Act of 1992 that paved the way firms to raise capital through fully market-determined rates. Subsequent laws expanded the use of credit derivatives and in 1999 the ban on forward trading was lifted. In addition, the stock exchanges were modernized and demutualized, while payments systems were upgraded. Importantly, bankruptcy and insolvency procedures were liberalized in 2002.

While these infrastructural reforms were lowering financial intermediation costs, a more market-oriented management of public debt also improved the efficiency of the financial system. Abandoning a long tradition, in 1992 the government began issuing debt at market-determined interest rates and in 1997 abolished automatic monetization of fiscal deficit through the issuance of treasury bills. This expanded the set of debt instruments very rapidly, as well as hedging tools such as interest swaps, forward and futures trading. The management of market liquidity was also made more efficient through the establishment of the repo market. While it is difficult to match the impact of these changes with the derived investment wedge, it is clear that the wedge, after remaining virtually constant through the 1980s, fell sharply after the first round of reforms in 1992 and then in the 2000s.

\footnotetext{
${ }^{7}$ Only the rate on savings deposit and that on interest charged on export credits are controlled by the Reserve Bank of India. In addition, banks are not allowed to exceed their declared prime rate for small loans. There are caps on margins for foreign borrowing and deposits from nonresident Indians.
} 
Compared to China, nonperforming loans were not a major problem in India, and while their reduction and the recapitalization of state-owned banks may have been helpful, they are unlikely to be major driver of the investment wedge.

This brings us to the role of borrowing constraints. Several firm-level studies have pointed to access to external finance as a major factor determining the growth of firms in India (Allen and others, 2007; Ghosh, 2006; Oura and Kohli, 2008). While there are tentative similarities between China and India in the rise in internal savings as a source of financing this s unlikely to be driven by a tightening in borrowing constraints in India. Recall that in China, firms responded to the tightening of borrowing constraints by increasing savings as that was the only source of collateral for bank loans. This is not the case in India given the vastly better

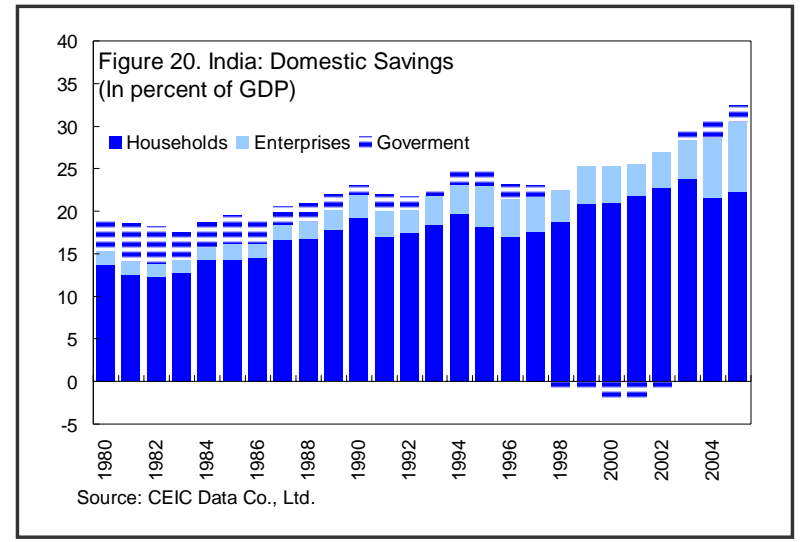
developed private property rights and even if that were to be the case the rise in internal savings has so far been rather modest. Instead in the case of India, borrowing constraints were likely to have been eased by the financial sector reforms.

While it is difficult to quantitatively calibrate any particular reform, the changes in the CRR and SLR rates could provide some quantifiable measure of how important financial reforms were. A relatively simple way of incorporating these reserve requirements is to assume that all household savings takes the form of deposits in a representative bank. The bank takes deposits from households, $l_{t}$, and gives out $\rho_{t}$ as the deposit interest rate in return, while charging $r_{t}$ as the lending rate to firms. The government preempts $\sigma_{t}$ fraction of the deposits. The deposits preempted by the government, $\sigma_{t} l_{t}$, is transferred to households in a lump sum manner. The firm borrows $\left(1-\sigma_{t}\right) l_{t}$ and converts it into capital $k_{t}=\left(1-\sigma_{t}\right) l_{t}$ and pays $\left(r_{t}-\delta\right)\left(1-\sigma_{t}\right) l_{t}$ at the end of production to the bank. The bank's profit is given by $\left(r_{t}-\delta\right)\left(1-\sigma_{t}\right) l_{t}-\rho_{t} l_{t}$, that under zero profit condition, implies that $\rho_{t}=\left(1-\sigma_{t}\right)\left(r_{t}-\delta\right)$.

The household's budget constraint is $c_{t}+\gamma_{t+1} n_{t+1} l_{t+1}-l_{t}=w_{t} e_{t}+\left(1-\sigma_{t}\right)\left(r_{t}-\delta\right) l_{t}+\pi_{t}$ and the economy's resource constraint is $c_{t}+\gamma_{t+1} n_{t+1} k_{t+1}-(1-\delta) k_{t}=y_{t}-\left(\pi_{t}+\sigma_{t} l_{t}-\gamma_{t+1} n_{t+1} \sigma_{t+1} l_{t+1}\right)$. Previously, the net transfers on the household were the taxes needed to finance government's expenditures $g_{t}$. Here $g_{t}=\pi_{t}+\sigma_{t} l_{t}-\gamma_{t+1} n_{t+1} \sigma_{t+1} l_{t+1}$. Thus depending on the sign of $\sigma_{t} l_{t}-\gamma_{t+1} n_{t+1} \sigma_{t+1} l_{t+1}$, the taxes needed to finance government expenditure could be smaller or larger than before. In particular, if $\sigma_{t+1}$ is not lowered too much compared to $\sigma_{t}$, then $\sigma_{t} l_{t}-\gamma_{t+1} n_{t+1} \sigma_{t+1} l_{t+1}>0$ and the needed tax for a given level of government spending will be 
less. This can be rewritten as $c_{t}+\gamma_{t+1} n_{t+1} k_{t+1}-(1-\delta) k_{t}=\left(1-g_{t}\right) y_{t}+\left(\sigma_{t} l_{t}-\gamma_{t+1} n_{t+1} \sigma_{t+1} l_{t+1}\right)$. It is not difficult to construct a more realistic but complicated setting where $\left(\sigma_{t} l_{t}-\gamma_{t+1} n_{t+1} \sigma_{t+1} l_{t+1}\right)$ is equivalent to the government's net purchase of bonds. As a result, $\pi_{t}$ can be thought of as the part of government expenditure financed through taxes, with the remaining financed by net purchases of bonds that are partially or fully financed through the preempted deposits.

Turning to the consumption function, it turns out that

$$
c_{t+1}=\frac{c_{t}}{\gamma_{t+1}} \beta\left[1+\left(1-\sigma_{t+1}\right)\left(\alpha\left(\frac{e_{t+1}}{k_{t+1}}\right)^{1-\alpha}-\delta\right)\right]
$$

Figure 21. India: Simulation with SLR
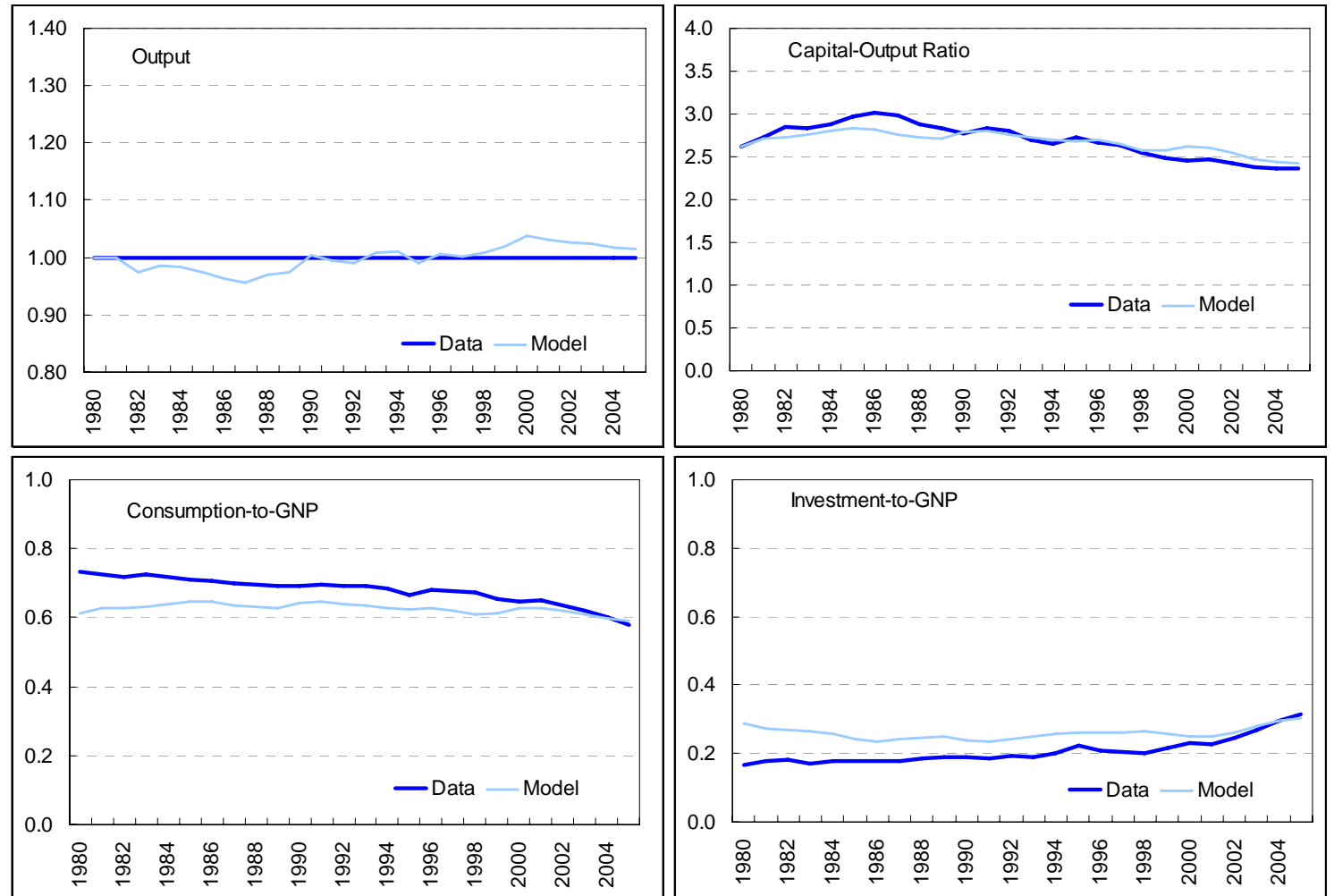

Source: Author's estimates.

which can be easily verified to be equivalent to (12) once more.

Two separate simulations were carried out. In the first, the sequence of $\left\{\sigma_{t}\right\}$ was proxied by the actual SLR for the period 1980-2005 and then assumed to be fixed at the average 2000-2005 level. In the second simulation $\left\{\sigma_{t}\right\}$ was proxied by both SLR and CRR. As shown in Figure 6, the results are encouraging. Using only SLR, the model mimics the data significantly better than under the standard Solow model set up. While the model does much better in the later years, in the earlier years simulated consumption is still too low and 
investment too high. The results after adding CRR are much better. The gap between simulated and actual consumption and investment narrows markedly in the earlier years, while the fit in the latter years is preserved.

Figure 22. India: Simulation with SLR and CRR
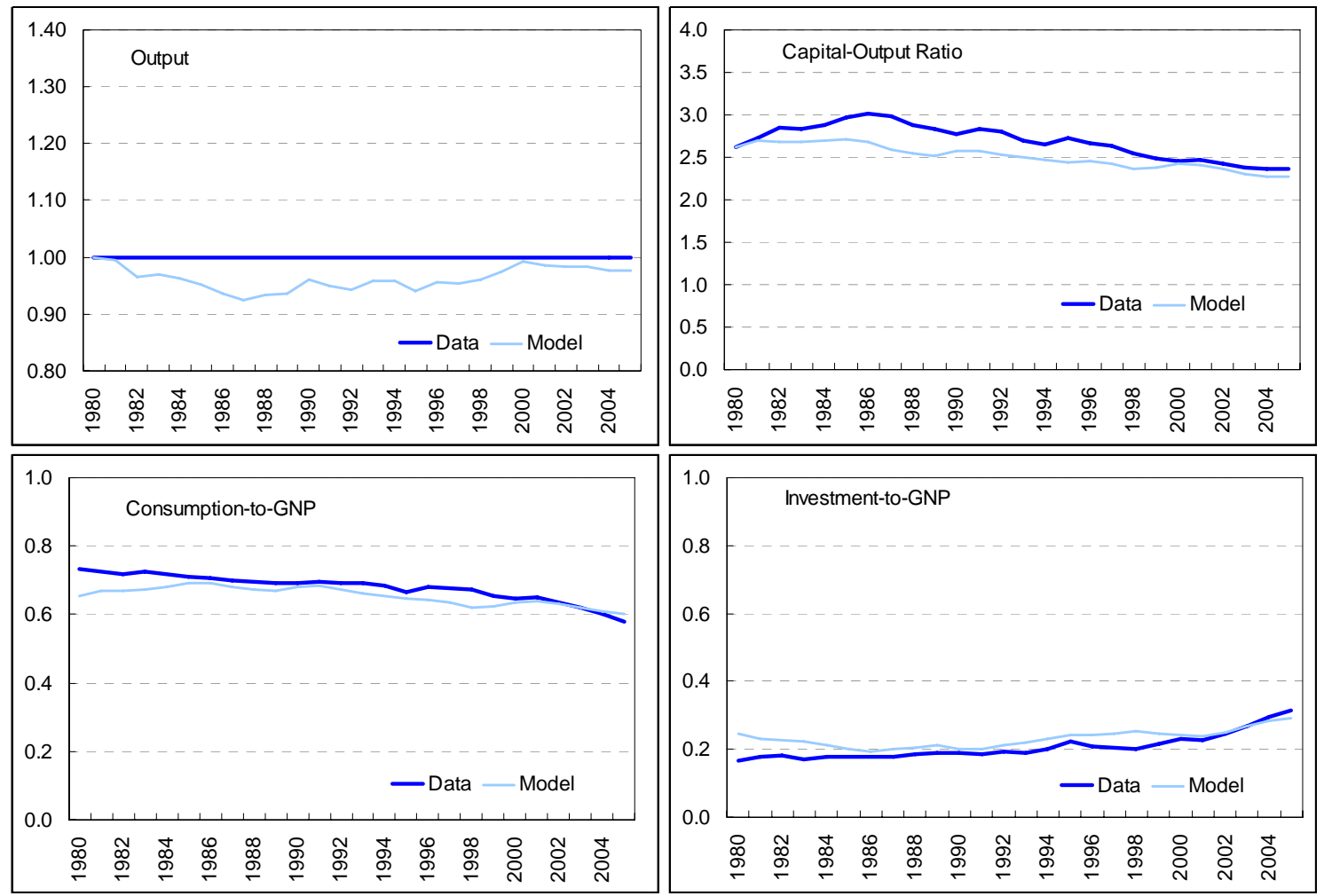

Source: Author's estimates.

\section{ConCLUSIONS}

The implication of the analysis in the previous sections is that financial distortions may be crucial in understanding China's and India's economic performances and that financial sector reform may turn out to be key in China's quest to rebalance growth and India's pursuit to raise its growth rate. This is not to suggest that other factors put forward in the other studies are not relevant. Rather the analysis suggests that the explanatory power of financial distortions may be quantitatively large and that focusing on reforming this sector may be quite important. Indeed, simulations based on the prototype economy discussed in the previous sections indicate that in the case of China if financial reforms were to remove these distortions - for example by raising the cost of capital to the effective capital income tax rate-the consumption-to-GNP could rise from its current level of below 40 percent to around 55 percent in steady state, which would imply that the investment-to-GNP ratio would fall to around 30 percent from its current level of over 45 percent. In the simulation, 
Figure 23. India: Simulating Policy Change
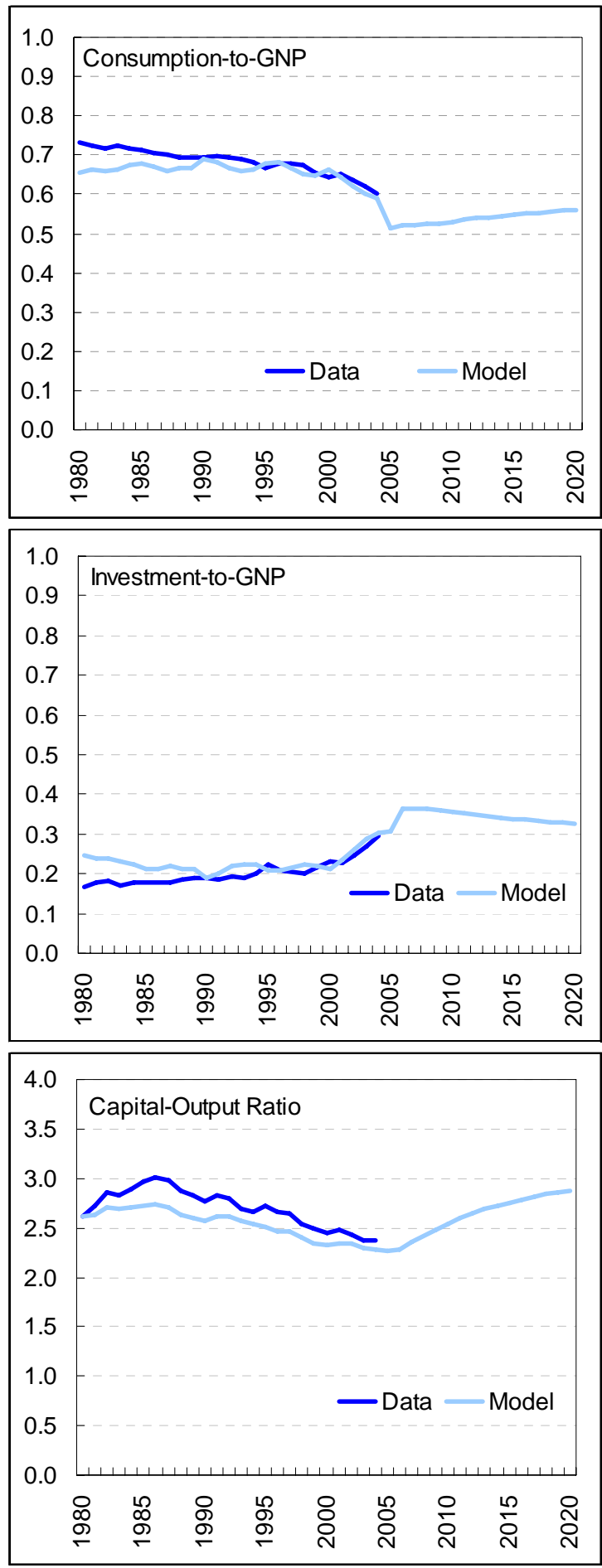

Source: Author's estimates.
Figure 24. China: Simulating Policy Change
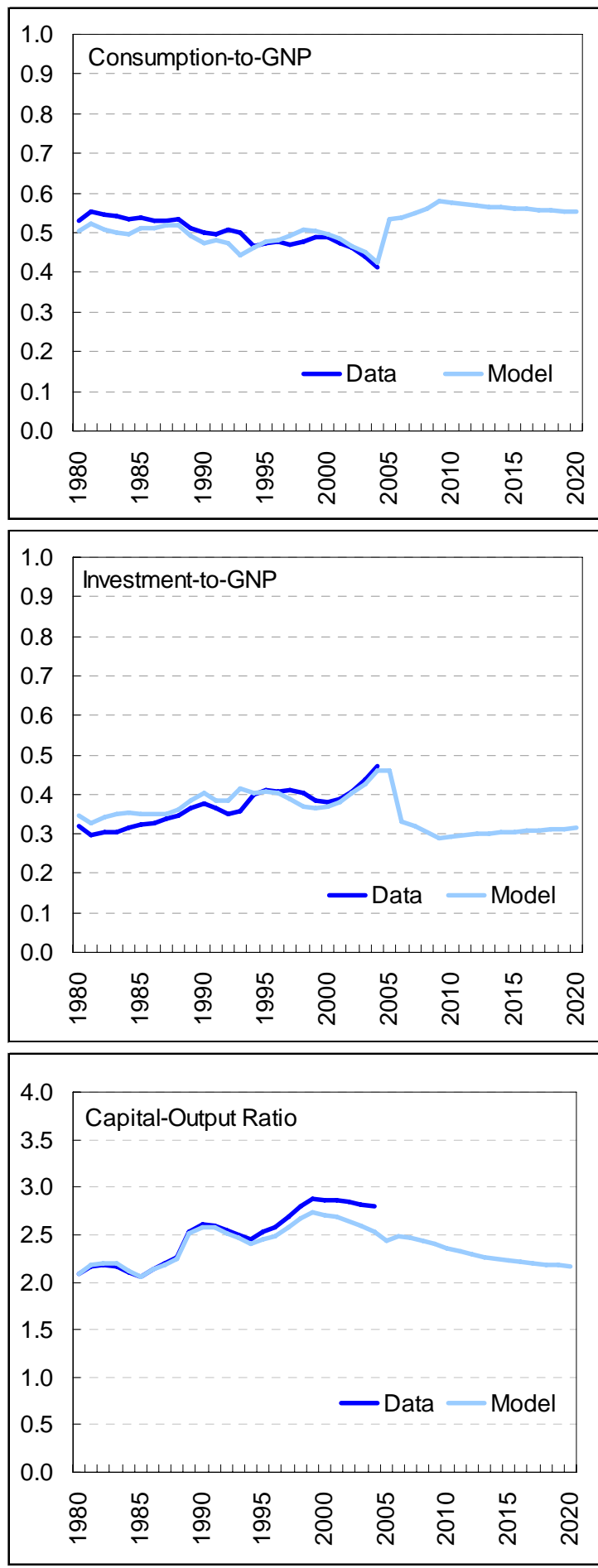

Source: Author's estimates.

the average growth rate of output would fall by around 2 percentage points below the average of the 1990s and 2000s to around 8 percent. Similarly in the case of India, reforms that lower the cost of capital to its average effective rate of capital income tax, would increase the 
investment-to-GDP ratio by another 5 percentage points over the medium term with 1-2 percentage points higher growth rate. ${ }^{8}$

Finally, a methodological issue: China's sustained double-digit growth rate over the last 25 years and India's rapid growth rate in the 2000s have, in a sense, surprised researchers, as they have been unprecedented. This has prompted many researchers to try to uncover the "China” or "India” model of development. What this paper suggests is that one need not look far beyond the neoclassical growth theory to uncover such a model. Many questions remain unanswered, such as what underlies the very high and sustained productivity growth? Is it really just technological progress or are some important elements being missed? Do the results change if the external sector for both China and India are endogenized? These are important questions for future research. Nonetheless, neoclassical growth theory provides empirically reasonable answers to some key questions: China's and India's high growth rate may just be the result of adding or removing distortions in financial incentives.

\footnotetext{
${ }^{8}$ In simulating the impact of such reforms, it was assumed that financial sector restructuring cuts the wedge on capital income from its 2005 level to that of the average effective rate of capital income tax of the 1990s and 2000s. All other parameters were left unchanged.
} 


\section{REFERENCES}

Allen, F., R. Chakrabarti, S. De, J. Qian, and M. Qian, 2007, "Financing Firms in India,” Financial Institution Centers No. 06-08 (Pennsylvania: The Wharton Financial Institutions Center). Available via Internet: http://fic.wharton.upenn.edu/fic/papers/06/p0608.htm.

Anderson, Jonathan, 2006, “How Real is China’s Bank Cleanup,” UBS Investment Research, Hong Kong. Available via Internet: www.ubs.com/economics.

Athukorala, P, and Kunal Sen, 2002, Saving, Investment, and Growth in India (New York: Oxford University Press).

Ayyagari. M., A. Demirguc-Kunt, A., and V. Maksimovic, 2008, "Formal versus Informal Finance: Evidence from China,” World Bank Policy Research Working Paper 4465 (Washington: The World Bank).

Aziz, Jahangir, 2006, "Rebalancing China’s Economy: What Does Growth Theory Tell Us?,” IMF Working Paper 06/291 (Washington: International Monetary Fund). , and C. Duenwald, 2003, "The Growth-Financial Development Nexus," in China: Competing in the Global Economy, ed. by Wanda Tseng and Markus Rodlauer (Washington: International Monetary Fund).

Aziz, Jahangir, and Li Cui, 2007, “Explaining China’s Low Consumption: The Neglected Role of Household Income,” IMF Working Paper 07/181 (Washington: International Monetary Fund).

Beck. T., R. Levine, and N. Loyaza, 2000, “Finance and the Sources of Growth,” Journal of Financial Economics, Vol. 58, pp. 261-300.

Bencivenga, V.R., and Bruce Smith, 1991, "Financial Intermediation and Endogenous Growth,” Review of Economic Studies, Vol. 58, pp. 195-209.

Bery, S., and K. Singh, 2006, "Domestic Financial Liberalization and International Financial Integration: An Indian Perspective," in China and India: Learning from Each Other Reforms and Policies for Sustained Growth, ed. by J. Aziz, S. Dunaway, and E. Prasad (Washington: International Monetary Fund).

Bosworth, B., and Susan Collins, 2007, “Accounting for Growth: Comparing China and India,” Economics of Developing Countries Papers, (Washington: Brookings Institution). , and A. Virmani, 2007, "Sources of Growth in the Indian Economy,” NBER Working Paper No. 12901 (Cambridge, Massachusetts: National Bureau of Economic Research).

Barnett, Steve, and Ray Brooks, 2006, “What’s Driving Investment in China?,” IMF Working Paper 06/265 (Washington: International Monetary Fund). 
Bergeoing, R., P.J. Kehoe, T.J. Kehoe, and Raimundo Soto, 2002, “A Decade Lost and Found: Mexico and Chile in the 1980s,” Review of Economic Dynamics, Vol. 5 (1), pp. 166-205.

Bernanke, B., and Mark Gertler, 1989,” Agency Costs, Net Worth, and Business Fluctuations,” American Economic Review, Vol. 79(1), pp. 14-31.

Carlstrom, C.T., and T.S. Fuerst, 1997, "Agency Costs, Net Worth, and Business Fluctuations: A Computable General Equilibrium Analysis,” American Economic Review, Vol. 87(5), pp. 893-910.

Chakraborty, Suparna, 2005, "Real Estate Prices, Borrowing Constraints and Business Cycles: A Study of the Japanese Economy,” Macroeconomics 0504012, EconWPA (Minneapolis: University of Minnesota).

Chari, VV., P.J. Kehoe, and Ellen R. McGrattan, 2006, “Business Cycle Accounting,” Research Department Staff Report 328 (Minneapolis: Federal Reserve Bank of Minneapolis). , 2002a, “Accounting for the Great Depression,” American Economic Review, Vol. 92(2), pp. 22-27. , 2002b, “Technical Appendix: Accounting for the Great Depression,” Working Papers 619 (Minneapolis: Federal Reserve Bank of Minneapolis).

Chow, Gregory C, 1993, “Capital Formation and Economic Growth in China," Quarterly Journal of Economics, Vol. 108 (3), pp. 809-842. , and K. Li, 2002, “China’s Economic Growth: 1952-2010,” Economic Development and Cultural Change, Vol. 15(1), pp. 247-256.

Demirguc-Kunt, A., and R. Levine, 2008, "Finance, Financial Sector Policy, and Long-Run Growth,” World Bank Policy Research Working Paper No. 4469 (Washington: The World Bank).

Dobson, Wendy, and Anil Kashyap, 2006, "The Contradiction in China’s Gradualist Banking Reforms,” Working Paper No. 609 (Toronto: University of Toronto, Joseph L. Rotman School of Management).

Fehr Hans, Sabine Jokisch, Laurence J. Kotlikoff, 2005, "Will China Eat Our Lunch or Take Us Out to Dinner? Simulating the Transition Paths of the U.S., EU, Japan, and China," NBER Working Paper No. 11668 (Cambridge, Massachusetts: National Bureau of Economic Research).

Ghosh, Saibal, 2006, "Did Financial Liberalization Ease Financing Constraint? Evidence from Indian Firm-Level Data,” Emerging Markets Review, Vol. 7, pp. 176-190.

Gollin, Douglas, 2002, “Getting Income Shares Right,” Journal of Political Economy, Vol. 110(2), pp. 58-474. 
Greenwood, J., and Boyan Jovanovic, 1990, "Financial Development, Growth, and Distribution of Income,” Journal of Political Economy, Vol. 98, pp. 1076-1107.

Hayashi, Fumio, and Edward C. Prescott, 2002, “The 1990s in Japan: A Lost Decade,” Review of Economic Dynamics, Vol. 5(1), pp. 206-35.

Heytens, Paul, and Harm Zebregs, 2003, “How Fast Can China Grow?,” in China: Competing in the Global Economy, ed. by Wanda Tseng and Markus Rodlauer (Washington: International Monetary Fund).

Huang, Yasheng, 2003, Selling China: Foreign Direct Investment during the Reform Era, Cambridge, United Kingdom: Cambridge University Press).

Karacadag, Cem, 2003, "Financial System Soundness and Reforms," in China: Competing in the Global Economy, ed. by Wanda Tseng and Markus Rodlauer (Washington: International Monetary Fund).

King, R., and R. Levine, 1993, “Finance and Growth: Schumpeter Might Be Right,” Quarterly Journal of Economics, Vol. 108, pp. 717-737.

Kobayashi, Keiichiro, and Masaru Inaba, 2006, "Borrowing Constraints and Protracted Recessions,” Research Institute of Economy, Trade and Industry Discussion Paper No. 06011 (Tokyo, Japan: Ministry of Economy, Trade and Industry).

Kydland, Finn, and Carlos Zarazaga, 2004, “Argentina’s Lost Decade,” Review of Economic Dynamics, Vol. 5(1), pp. 152-65.

Lardy, Nicholas, 1998, China's Unfinished Economic Revolution (Washington: Brookings Institution Press).

Mauro, P, 1995, "Stock Markets and Growth: A Brief Caveat on Precautionary Savings,” Economic Letters, Vol. 47, pp. 111-116.

Mohan, Rakesh, 2005, "Financial Sector Reforms in India: Policies and Performance Analysis," Economic and Political Weekly, Vol. 40(12), pp. 1106-1121.

Myers, S.C., and N.S. Majluf, 1984, "Corporate Financing and Investment Decisions when Firms have Information That Investors Do Not Have,” Journal of Financial Economics, Vol. 13(2), pp. 187-221.

National Bureau of Statistics, China Statistical Yearbook (Beijing, various issues).

Nehru, Vikram, E. Swanson, and A. Dubey, 1993, “A New Database on Human Capital Stock: Sources, Methodology, and Results,” World Bank Policy Research Paper Series No. 1124 (Washington: The World Bank).

Oura, H., and R. Kohli, 2008, "Financial Development and Growth in India: A Growing Tiger in a Cage?,” IMF Working Paper 08/xx (forthcoming). 
Pagano, M., 1993, "Financial Markets and Growth: An Overview,” European Economic Review, Vol. 37, pp. 613-622.

Panagariya, A, 2004, “India in the 1980s and 1990s: A Triumph of Reforms,” IMF Working Paper, 04/43 (Washington: International Monetary Fund).

Podpiera, Richard, 2006, “Progress in China’s Banking Sector Reform: Has Bank Behavior Changed?,” IMF Working Paper, 06/71 (Washington: International Monetary Fund).

Poirson, H., 2006, “The Tax System in India: Could Reform Spur Growth,” IMF Working Paper 06/93 (Washington: International Monetary Fund).

Rajan, R. and L. Zingales, 1998, "Financial Dependence and Growth,” American Economic Review, Vol. 88, pp. 559-586.

Schumpeter, J.A., 1911, The Theory of Economic Development (London: Oxford University Press, reprinted 1969).

Singh, A., 1997, "Financial Liberalisation, Stock Markets and Economic Development," Economic Journal, Vol. 107, pp. 771-782.

Singh, C., 2005, “Financial Sector Reforms in India,” SCID Working Paper No. 241 (Stanford, California: Stanford Center for International Development). 